\title{
Evaporation from cultivated and semi-wild Sudanian Savanna in west Africa
}

\author{
Natalie C. Ceperley ${ }^{1,2}$, Theophile Mande ${ }^{2}$, Nick van de Giesen ${ }^{3}$, Scott Tyler ${ }^{4}$, Hamma Yacouba ${ }^{5}$, and \\ Marc B. Parlange ${ }^{1,2}$ \\ ${ }^{1}$ Department of Civil Engineering, Faculty of Applied Sciences, University of British Columbia, Vancouver, \\ British Columbia, Canada \\ ${ }^{2}$ Laboratory of Environmental Fluid Mechanics and Hydrology, School of Architecture, Civil and Environmental \\ Engineering, Swiss Federal Institute of Technology, Lausanne, Switzerland \\ ${ }^{3}$ Department of Civil Engineering and Geosciences, Delft University of Technology, Delft, the Netherlands \\ ${ }^{4}$ Department of Geological Sciences \& Engineering, University of Nevada, Reno, NV, USA \\ ${ }^{5}$ Laboratory Hydrology and Resources in Water, International Institute for Water and Environmental Engineering (2iE), \\ Ouagadougou, Burkina Faso
}

Correspondence to: Natalie C. Ceperley (natalie.ceperley@unil.ch)

Received: 20 December 2016 - Discussion started: 16 January 2017

Revised: 4 July 2017 - Accepted: 16 July 2017 - Published: 22 August 2017

\begin{abstract}
Rain-fed farming is the primary livelihood of semi-arid west Africa. Changes in land cover have the potential to affect precipitation, the critical resource for production. Turbulent flux measurements from two eddy-covariance towers and additional observations from a dense network of small, wireless meteorological stations combine to relate land cover (savanna forest and agriculture) to evaporation in a small $\left(3.5 \mathrm{~km}^{2}\right)$ catchment in Burkina Faso, west Africa. We observe larger sensible and latent heat fluxes over the savanna forest in the headwater area relative to the agricultural section of the watershed all year. Higher fluxes above the savanna forest are attributed to the greater number of exposed rocks and trees and the higher productivity of the forest compared to rain-fed, hand-farmed agricultural fields. Vegetation cover and soil moisture are found to be primary controls of the evaporative fraction. Satellite-derived vegetation index (NDVI) and soil moisture are determined to be good predictors of evaporative fraction, as indicators of the physical basis of evaporation. Our measurements provide an estimator that can be used to derive evaporative fraction when only NDVI is available. Such large-scale estimates of evaporative fraction from remotely sensed data are valuable where groundbased measurements are lacking, which is the case across the African continent and many other semi-arid areas. Evaporative fraction estimates can be combined, for example, with
\end{abstract}

sensible heat from measurements of temperature variance, to provide an estimate of evaporation when only minimal meteorological measurements are available in remote regions of the world. These findings reinforce local cultural beliefs of the importance of forest fragments for climate regulation and may provide support to local decision makers and rural farmers in the maintenance of the forest areas.

\section{Introduction}

The Sudanian savanna in southeastern Burkina Faso is a patchwork of savanna, forest, and scrubland with some patches more representative of the drier Sahel and others more representative of the more humid Guinean forests. Vegetation is mainly deciduous according to seasonal moisture availability, but spatial variations in topography, water availability, and plant communities result in some variation in greenness and some evergreen species, for example, near the springs. Historically, people in this region rely on a mix of hunting and gathering, small-scale agriculture, and pastoralism. As land claims and regulations have changed, communities have been forced to rely more on agricultural production as a primary source of food and income, resulting in land conversion for agriculture. Today, small-scale, rain-fed 
agriculture is the dominant livelihood in large parts of west Africa, despite its high level of dependence on seasonally controlled hydrology. Conversion of the landscape to agriculture involves removing rocks, trees, and natural grasses, and tilling the soil (Swanson, 1978). Transformation of forest land to agriculture has been shown by model simulations to alter global circulation, hydrology, and biogeochemistry both in the present and in predictions of the future (Abiodun et al., 2008; Feddema et al., 2005; Mande et al., 2011; Steiner et al., 2009; Sylla et al., 2015; Vitousek, 1997).

Modification of the land surface results in changes to the physical environment, and specifically hydrological fluxes, by altering the components of the surface energy budget (Pielke et al., 2002). The partition of net radiation into sensible heat, evaporation, and soil heat flux drives global atmospheric processes and is controlled by interacting surface and atmospheric conditions (Foken, 2008; Szilagyi and Parlange, 1999).

The energy balance is challenging to close even in areas and regions with extensive datasets and accessibility, and is particularly challenging in areas with complex surfaces (Burba, 2013; Domingo et al., 2011; Farhadi, 2012; Federer et al., 2003; Foken et al., 2009; Guo et al., 2006; Katul and Parlange, 1992; Krishnan et al., 2012; Kustas et al., 1994; Parlange and Katul, 1992; Williams et al., 2012). Evaporation from vegetated surfaces remains the component of the global distribution of water that is the least frequently measured and thus the least well understood (Brutsaert, 1982; Brutsaert and Parlange, 1992; Burba, 2005; Compaore, 2006; Crago, 1996; Crago and Qualls, 2013), particularly in west Africa, due to limited field observations (Bagayoko et al., 2007; Dolman et al., 1997; Gash et al., 1997; Mande et al., 2011). A connection exists between changes in albedo and the occurrence of drought in west Africa, although the physical processes and direct implications for desertification are debatable (Charney, 1975; Nicholson et al., 1998).

The evaporative fraction, the ratio of latent heat flux to available energy, is useful to estimate total daily evaporation with measurements of a single component of the energy balance and to upscale surface measurements using remote sensing products (Brutsaert and Sugita, 1992; Compaore, 2006; Porte-Agel et al., 2000; Shuttleworth et al., 1989; Szilagyi et al., 1998; Szilagyi and Parlange, 1999). Using evaporative fraction to calculate the total daily evaporation is based on the concept of self-preservation in the diurnal evolution of the surface energy budget (Brutsaert and Sugita, 1992; PorteAgel et al., 2000), stating that the diurnal cycle of each of the energetic fluxes will resemble that of available energy, even if there is variation in the quantity, allowing for exploiting satellite data that are typically only obtainable once a day at best. Remotely sensed land surface temperature is currently the primary tool for mapping the surface energy budget over a large area (Bateni and Entekhabi, 2012). Evaporative fraction is constant during daytime in fair weather conditions (Gentine et al., 2007) but can be much less constant when moisture circulation rates are high and available soil moisture increases (Lhomme and Elguero, 1999). Seasonal progression of evaporative fraction response to rainfall and moisture availability can depend on surface conditions. For example, it can respond faster in grassland than in woodland (Farah et al., 2004). These variations are not explained by meteorological conditions, including cloudiness alone, but rather change in surface resistance and moisture advection and availability (Farah et al., 2004; Lohou et al., 2010, 2014).

We measured the energetic and hydrologic fluxes in two sites of a semi-arid, mixed-use catchment over a year and a half, capturing both the greening and dry-down phases. The land is used as an agroforestry parkland that is farmed every 2-3 years, and contains a forested area made up of evergreen trees arranged in a gallery forest surrounding a spring and an open wooded savanna (savanna forest) on a plateau about $100 \mathrm{~m}$ above the surrounding land. These land covers are representative of the surrounding region and capture the range from more to less anthropogenic land uses. The multi-use comparison over multiple seasonal cycles puts this study among the few recent, long-term studies in this region (Bagayoko et al., 2007; Brümmer et al., 2008; Ezzahar et al., 2009; Guichard et al., 2009; Guyot et al., 2009, 2012, Lohou et al., 2010, 2014; Mamadou et al., 2014, 2016; Mauder et al., 2006; Ramier et al., 2009; Timouk et al., 2009; Velluet et al., 2014). We calculate the evaporative fraction over the study period and compare it with land cover and atmospheric controls, in order to provide estimation based on the physical basis of fluxes. Our measurements are significant because they allow calibration and comparison for calculation of the components of the energy budget from lower cost and more easily maintained stations (Nadeau et al., 2009; Simoni et al., 2011) and corresponding data from satellite imagery. This study has implications for development priorities, as it takes place in context where local livelihood can be dramatically affected by slight changes in the water balance and land cover.

\section{Measurements and calculations}

\subsection{Site description}

Observations were made in a small catchment $\left(3.5 \mathrm{~km}^{2}\right.$ area) neighboring the village of Tambarga in the commune of Madjoari, in the Gourma province, in Burkina Faso, west Africa (Fig. 1). The ephemeral stream defining the catchment (outlet located at $11^{\circ} 26^{\prime} 29.7^{\prime \prime} \mathrm{N} 1^{\circ} 12^{\prime} 57.7^{\prime \prime} \mathrm{E}$ ) flows into the Singou River, which joins the Pendjari River and eventually flows into the White Volta of the Volta River basin, the third largest river basin by area in west Africa, after the Niger and the Senegal. A rocky escarpment defines the catchment with a plateau on average some $100 \mathrm{~m}$ above the lower agricultural fields, and the soil is predominantly sandy loam (Ceperley, 2014). These fields are the "house" farms and are smaller 


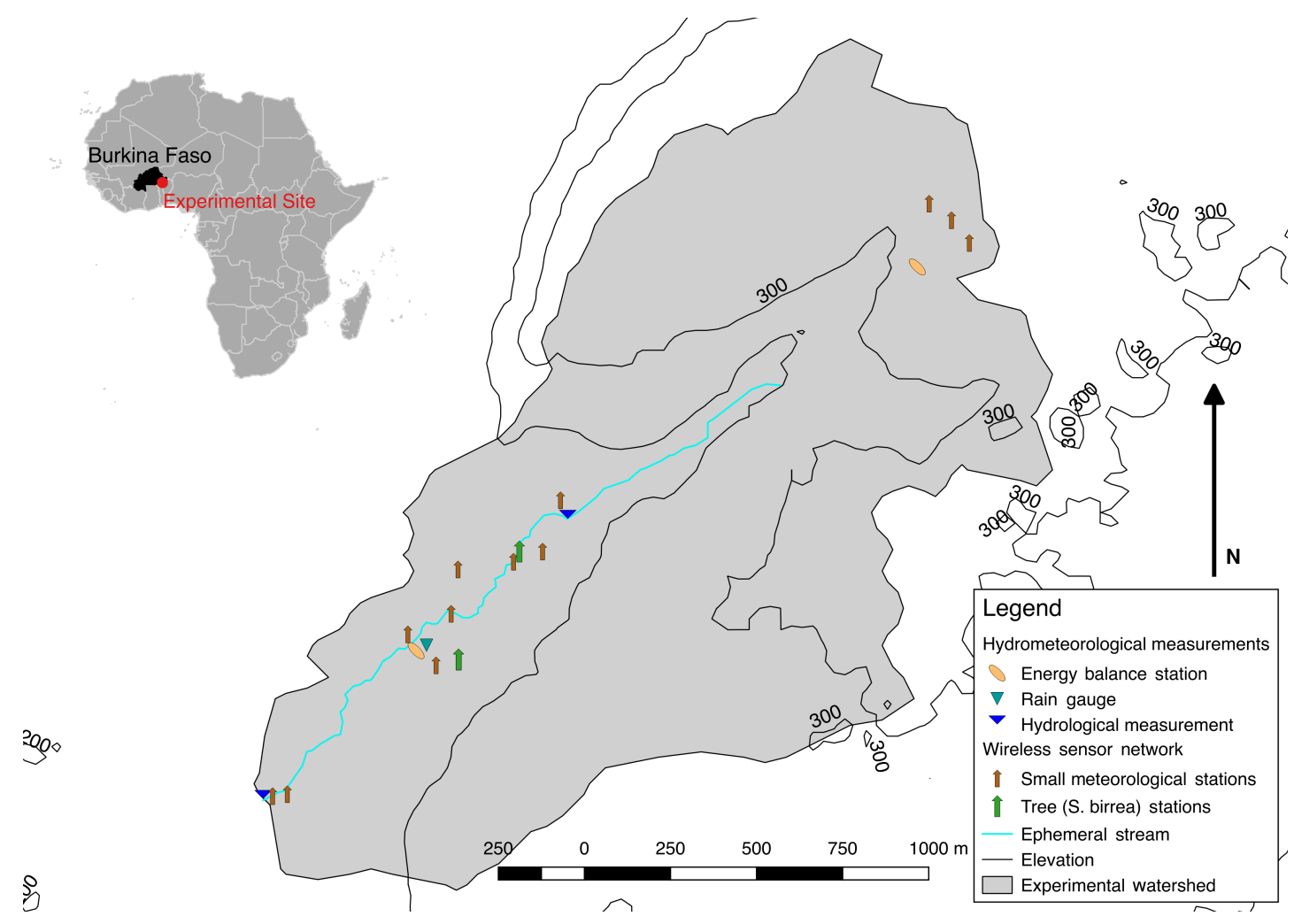

Figure 1. Map of experimental watershed. The site is located next to the village of Tambarga, in the southeastern corner of Burkina Faso, west Africa. Energy balance stations, small meteorological stations, including those near agroforestry trees, and hydrologic monitoring stations are shown. Springs are located at the source of the ephemeral stream, at the base of the rocky escarpment.

than the main revenue farms. In 2009, they were farmed with short rotation millet and in 2010 they were left fallow. Plowing occasionally uses animal-drawn plows, but is primarily done by hand - this is not intensive agriculture. The open wooded savanna (savanna forest) on top of the rocky escarpment and rain-fed grain (corn or millet) are the two dominant land covers of the catchment according to area. At opposite ends of the catchment, there is a dense gallery forest in the valley that grows near perennial springs and an ephemeral wetland used for rice cultivation near the point considered the outlet of the watershed. The existence of a raised plateau with perennial springs suggests that there may be lateral subsurface water transfer. Farming is the main livelihood in the village, and crops include millet, sorghum, cotton, and rice. Agroforestry trees in the fields are common and consist most often of the tree species Vitellaria paradoxa, Sclerocarya birrea, and Ficus sp. (Bordes, 2010; see Table 2). Burning mostly occurs between November and January, but occasionally there is a fire in February or March. The village is made up of a majority of people from the Gourmantché ethnic group, though there is a significant population of Fulani (Peulh), and some migrants from other areas of Burkina Faso or neighboring countries (Ceperley, 2014).

The watershed falls in the Sudanian zone of the west African monsoon climate system, defined by alternating wet and dry seasons, with the rain falling between May and September. The natural vegetation is Sudanian wooded savanna, composed of a mix of deciduous woody trees, shrubs, and tall grasses. In addition, due to the variation in topography and water availability, there are gallery forests near streams or rivers that contain many species endemic further south in the Guinean zone. The surrounding area is a patchwork of hunting reserves and national parks and thus has a higher level of vegetation cover than most of the country. This watershed is a prime location to study the consequences of land use change from Sudanian savanna to agricultural fields, since it contains both open wooded savanna that has not been memorably farmed and regularly farmed fields. Agriculture is primarily rain-fed and not mechanized corn and millet cultivation. In addition, the surrounding Sudanian savanna, which is characterized by fire-selected grasses ranging from $20 \mathrm{~cm}$ to $1.5 \mathrm{~m}$ in height, also includes patches of woody scrubland, open forests, gallery forests, and riparian stands (Arbonnier, 2004). Inventory of woody species taller than breast height in the two major land covers was inventoried by family, chorology, and life form (according to Adamou, 2005) and is reported in Table 2. 
Table 1. Inventory of instruments used for energy balance analysis. The name of the sensor or instrument is followed by the measurement it performs, the height and depth of each sensor, the total number used, and the interval of measurement. The heights were identical at both measurement points.

\begin{tabular}{|c|c|c|c|c|c|}
\hline Instrument & Measurement & Height/depth & Number & Interval & Time span \\
\hline $\begin{array}{l}\text { CSAT-3 sonic anemometer } \\
\text { (Campbell Scientific, Logan, } \\
\text { UT, USA) }\end{array}$ & $\begin{array}{l}\text { 3-D wind speed and } \\
\text { direction, air tempera- } \\
\text { ture }\end{array}$ & $2.2 \mathrm{~m}$ & 3 & $\begin{array}{l}20 \mathrm{~Hz} \text {, proc. } \\
30 \mathrm{~min}\end{array}$ & May 2009-October 2010 \\
\hline $\begin{array}{l}\text { LI-7500 infrared gas analyzer } \\
\text { (LICOR, Lincoln, NE, USA) }\end{array}$ & $\mathrm{H}_{2} \mathrm{O}$ concentration & $2.2 \mathrm{~m}$ & 3 & $\begin{array}{l}20 \mathrm{~Hz} \text {, proc. } \\
30 \mathrm{~min}\end{array}$ & May 2009-October 2010 \\
\hline $\begin{array}{l}\text { CNR2 radiometer (Kipp \& Zo- } \\
\text { nen, Delft, the Netherlands) }\end{array}$ & SW LW radiation & $2.1 \mathrm{~m}$ & 2 & $1 \mathrm{~min}$ & October 2009-October 2010 \\
\hline $\begin{array}{l}\text { HMP450 (Campbell Scientific, } \\
\text { Logan, UT, USA) with radia- } \\
\text { tion shield }\end{array}$ & $\begin{array}{l}\text { Air temperature, air } \\
\text { humidity }\end{array}$ & $2.25 \mathrm{~m}$ & 2 & $1 \mathrm{~min}$ & May 2009-October 2010 \\
\hline $\begin{array}{l}\text { Pluviometer } 3029 \text { (Précis } \\
\text { Mécanique, Bezons CEDEX, } \\
\text { France) }\end{array}$ & Precipitation & $1 \mathrm{~m}$ & 1 & $0.1 \mathrm{~mm}$ & May 2009-January 2015 \\
\hline $\begin{array}{l}\text { Davis Instruments (Hayward, } \\
\text { CA, USA) }\end{array}$ & Precipitation & $0.2 \mathrm{~m}$ & 12 & $1 \mathrm{~min}$ & May 2009-January 2015 \\
\hline $\begin{array}{l}\text { Davis Instruments (Hayward, } \\
\text { CA, USA) }\end{array}$ & $\begin{array}{l}\text { Shortwave solar } \\
\text { radiation, incoming }\end{array}$ & $1.8 \mathrm{~m}$ & 12 & $1 \mathrm{~min}$ & May 2009-January 2015 \\
\hline $\begin{array}{l}\text { Infrared thermometer TN901 } \\
\text { (Zytemp, Taiwan, R.O.C.) }\end{array}$ & Surface temperature & $1.1 \mathrm{~m}$ & 12 & $1 \mathrm{~min}$ & May 2009-January 2015 \\
\hline $\begin{array}{l}\text { SHT7 (Sensiron AG, Staefa } \\
\text { Zurich, Switzerland) }\end{array}$ & $\begin{array}{l}\text { Air temperature and } \\
\text { humidity }\end{array}$ & $1.7 \mathrm{~m}$ & 12 & $1 \mathrm{~min}$ & May 2009-January 2015 \\
\hline $\begin{array}{l}\text { 5TM, 5TE, ECTM (Decagon, } \\
\text { Pullman, WA, USA) }\end{array}$ & Soil humidity & $5-30 \mathrm{~cm}$ & $\begin{array}{l}24 \\
\text { (varied) }\end{array}$ & $1 \mathrm{~min}$ & May 2009-January 2015 \\
\hline
\end{tabular}

\subsection{Field measurements}

Two energy balance stations were installed from May 2009 to September 2010. One was situated in an agricultural field planted with short season millet in 2009 and left fallow in 2010 , and the second one measured over the gallery forest when the wind came from the west $\left(90^{\circ} \pm 45^{\circ}\right)$ and over the open wooded savanna when the wind came from the south $\left(180^{\circ} \pm 45^{\circ}\right)$. They were equipped with sonic anemometers, infrared open-path gas analyzers, net radiometers, and air temperature and humidity sensors (Table 1). Eddy-covariance equipment was placed facing two opposite directions $\left(46\right.$ and $226^{\circ}$ ) on the lower station over the field and in the dominant wind direction on the upper station over the gallery forest. The distance between the two measurement points was approximately $1 \mathrm{~km}$ and $100 \mathrm{~m}$ of height difference. Near the station in the field was a high-precision rain gauge measuring at a resolution of $0.1 \mathrm{~mm}$. In addition, a network of up to 12 small meteorological stations (Ingelrest et al., 2010) was distributed across the watershed with sensors to measure incoming solar radiation, wind direction and speed, air temperature and relative humidity, rainfall, soil moisture and temperature, and surface temperature. In this analysis, we use data from May 2009 to October 2010, the 15 months with both towers operational, but when possible, we present the longest time series possible for climatic context. We attempted to measure ground heat flux using heat flux plates but ultimately rejected the observations because of irregularities in the land surrounding the plates.

\subsection{Flux calculation}

The surface energy budget is written in Eq. (1):

$R_{\mathrm{n}}=L_{\mathrm{e}} E+H+G$,

where $L_{\mathrm{e}} E$ is latent heat flux, $H$ is sensible heat flux, $R_{\mathrm{n}}$ is the net radiation, and $G$ is the soil heat flux, all in watts per square meter $\left(\mathrm{W} \mathrm{m}^{-2}\right)$.

The sensible heat is expressed in Eq. (2):

$H=\rho c_{p} \overline{w^{\prime} T^{\prime}}$,

where $\rho$ is the air density $\left(\mathrm{kg} \mathrm{m}^{-3}\right), c_{p}$ is the specific heat $\left(\mathrm{J} \mathrm{kg}^{-1} \mathrm{~K}^{-1}\right)$, and $w^{\prime} T^{\prime}$ is the covariance of fluctuations of 
Table 2. Inventory of species found in both agricultural field site and savanna forest site.

\begin{tabular}{|c|c|c|c|}
\hline \multicolumn{4}{|c|}{ Inventory of woody vegetation in savanna forest (1 ha) } \\
\hline Acacia macrostachya & Leg.-Mim. & $\mathrm{mph}$ & $\mathrm{S}$ \\
\hline Burkea africana & Leg.-Caes. & $\mathrm{mph}$ & SZ \\
\hline Combretum nigricans & Combretaceae & $\mathrm{mph}$ & S \\
\hline Daniellia oliveri & Leg.-Caes. & $\mathrm{MPh}$ & SZ \\
\hline Detarium microcarpum & Leg.-Caes. & $\mathrm{mph}$ & S \\
\hline Gardenia erubescens & Rubiaceae & nph & $\mathrm{S}$ \\
\hline Grewia flavescens & Tiliaceae & Lmph & GC \\
\hline Guiera senegalensis & Combretaceae & nph & SZ \\
\hline Hymenocardia acida & Euphorbiaceae & $\mathrm{mph}$ & SZ \\
\hline Lannea acida & Anacardiaceae & $\mathrm{mPh}$ & $\mathrm{S}$ \\
\hline Parkia biglobosa & Leg.-Mim. & $\mathrm{mPh}$ & $S$ \\
\hline Prosopis africana & Leg.-Mim. & $\mathrm{mPh}$ & $\mathrm{S}$ \\
\hline Pteleopsis suberosa & Combretaceae & $\mathrm{mph}$ & SZ \\
\hline Pterocarpus erinaceus & Leg.-Pap. & $\mathrm{mPh}$ & S \\
\hline Sclerocarya birrea & Anacardiaceae & $\mathrm{mph}$ & $\mathrm{S}$ \\
\hline Sterculia setigera & Sterculiaceae & $\mathrm{mph}$ & $\mathrm{S}$ \\
\hline Strychnos spinosa & Loganiaceae & $\mathrm{LmPh}$ & PAL \\
\hline Terminalia avicennioides & Combretaceae & $\mathrm{mph}$ & S \\
\hline Terminalia laxiflora & Combretaceae & $\mathrm{mPh}$ & $\mathrm{S}$ \\
\hline Terminalia schimperiana (glaucescens) & Combretaceae & $\mathrm{mph}$ & $\mathrm{S}$ \\
\hline Terminalia mollis & Combretaceae & $\mathrm{mph}$ & PRA \\
\hline Vitellaria paradoxa & Sapotaceae & $\mathrm{mPh}$ & S \\
\hline Ximenia americana & Olacaceae & nph & $\mathrm{Pt}$ \\
\hline \multicolumn{4}{|c|}{ Inventory of woody vegetation in agricultural fields } \\
\hline Acacia sieberiana & Leg.-Mim. & $\mathrm{mph}$ & SZ \\
\hline Bombax costatum & Bombacaceae & $\mathrm{mph}$ & $\mathrm{S}$ \\
\hline Detarium microcarpum & Leg.-Caes. & $\mathrm{mph}$ & $\mathrm{S}$ \\
\hline Ficus sp. & Moraceae & $\mathrm{MPh}$ & \\
\hline Lannea sp. & Anacardiaceae & $\mathrm{mPh}$ & S/SZ \\
\hline Piliostigma reticulatum & Leg.-Caes. & $\mathrm{mph}$ & SG \\
\hline Sclerocarya birrea & Anacardiaceae & $\mathrm{mph}$ & S \\
\hline Terminalia schimperiana (glaucescens) & Combretaceae & $\mathrm{mph}$ & $\mathrm{S}$ \\
\hline Terminalia laxiflora & Combretaceae & $\mathrm{mPh}$ & $\mathrm{S}$ \\
\hline Terminalia mollis & Combretaceae & $\mathrm{mph}$ & PRA \\
\hline Ziziphus mauritiana & Rhamnaceae & $\mathrm{mph}$ & PAL \\
\hline Chorology & & No. & \\
\hline S & Sudanian & 19 & \\
\hline SZ & Sudano-Zambezian & 6 & \\
\hline GC & Guineo-Congolian & 1 & \\
\hline PAL & Paleotropical & 1 & \\
\hline $\mathrm{Pt}$ & Pantropical & 1 & \\
\hline SG & Sudano/Guinean transition & 1 & \\
\hline PRA & Pluriregional African & 1 & \\
\hline \multicolumn{4}{|l|}{ Abbreviations } \\
\hline Leg.-Caes. & Leguminosae-Caesalpinioideae & & \\
\hline Leg.-Mim. & Leguminosae-Mimosoideae & & \\
\hline Leg.-Pap. & Leguminosae-Papilionoideae & & \\
\hline \multicolumn{4}{|l|}{ Life forms } \\
\hline $\mathrm{mph}$ & microphanerophyte & $2-8 \mathrm{~m}$ & \\
\hline MPh & megaphanerophyte & $>30 \mathrm{~m}$ & \\
\hline nph & nanophanerophyte & $0.5-2 \mathrm{~m}$ & \\
\hline $\mathrm{L}$ & Liana & & \\
\hline $\mathrm{mPh}$ & mesophanerophyte & $8-30 \mathrm{~m}$ & \\
\hline
\end{tabular}


vertical wind speed $\left(\mathrm{m} \mathrm{s}^{-1}\right)$ and temperature $(\mathrm{K})$. Latent heat flux is expressed in Eq. (3):

$L_{\mathrm{e}}=L_{\mathrm{e}} \rho \overline{w^{\prime} q^{\prime}}$

where $L_{\mathrm{e}}$ is the latent energy of vaporization $\left(\mathrm{J} \mathrm{g}^{-1}\right)$ and $w^{\prime} q^{\prime}$ is covariance of fluctuations of vertical wind speed $\left(\mathrm{m} \mathrm{s}^{-1}\right)$ and humidity $\left(\mathrm{g} \mathrm{m}^{-3}\right)$.

All measurements were taken at $10 \mathrm{~Hz}$, and fluxes of sensible $(H)$ and latent $\left(L_{\mathrm{e}} E\right)$ heat were calculated at a half-hour time step using the covariance calculations as written above. Only daylight measurements, consistently between sunrise and sunset (08:00-16:00 UTC), corresponding to when energetic fluxes were of significant magnitude, were used for the comparison. The total of turbulent fluxes, $H+L_{\mathrm{e}} E$, was subtracted from the net radiation, $R_{\mathrm{n}}$, to give an indicator of ground heat flux ( $G$; see Eq. 1), any unaccounted for flux transfers, and the error (Brutsaert, 1982; Higgins, 2012).

We used a planar fit correction that effectively tilted measurements of the three components of the wind field perpendicular to the direction of flow, so that the vertical wind was equal to zero over 1-month averaging periods (Aubinet et al., 2012; Burba, 2005; Oldroyd et al., 2015; Rebmann et al., 2012; Wilczak et al., 2001). We then performed a linear regression using the mean wind vectors to obtain a matrix that we used to adjust wind vectors and stress tensors in a new coordinate system with a $z$ axis perpendicular to the mean streamline. Finally, we rotated the intermediate winds and stress tensors. The Webb-Pearman-Leuning equation (Foken et al., 2012; Leuning, 2007; Webb et al., 1980):

$E=(1+\mu \sigma)\left(\overline{\omega^{\prime} \rho^{\prime}}\right)+\frac{\bar{T}}{\overline{\rho_{\mathrm{v}}}} \overline{\omega^{\prime} T^{\prime}}$

was used to correct for any influence of trace gas concentrations on temperature and humidity fluctuations.

\subsection{Evaporative fraction}

Evaporative fraction (EF) was calculated for each half hour of data, separately over the savanna forest and the agricultural area by dividing the latent heat flux by the available energy, which is equivalent to the sum of sensible and latent heat fluxes. Although the true measure of available energy would be the difference between the net radiation and the ground heat flux, the sum of the turbulent fluxes, $H$ and $L_{\mathrm{e}} E$, was deemed more accurate given the rejection of our ground heat flux measurement. The midday average (10:0014:00 UTC) was used as the EF for a given day as that is when it was the most stable over the year (Fig. 3):

$\mathrm{EF}=\frac{L_{\mathrm{e}} E}{H+L_{\mathrm{e}} E}$.

\subsection{Volumetric water content}

Volumetric water content (VWC, $\mathrm{m}^{3} \mathrm{~m}^{-3}$ ) in the soil was monitored at 15 and $30 \mathrm{~cm}$ depths in 2009 and at 5 and $20 \mathrm{~cm}$ depths thereafter at some of the small meteorological stations representative of the various land covers (Table 1) using a measure of soil dielectric permittivity and converted to VWC (Topp et al., 1980). Measurements were averaged on the halfhour time step for comparison with EC measurements and by day for comparison with EF. Gaps in measurement were due to sensor malfunction. A vertical spatial average of measurements at various depths was used to obtain a continuous record for the watershed.

\subsection{Cloud cover}

Cloud cover was calculated by dividing the incoming shortwave radiation $\left(\mathrm{W} \mathrm{m}^{-2}\right)$ measured with a radiometer $(\mathrm{Ta}-$ ble 1) at each small meteorological station by the theoretical incoming radiation $\left(\mathrm{W} \mathrm{m}^{-2}\right)$ calculated with a simple model (Whiteman and Allwine, 1986) for each of the small meteorological stations operating on any given day:

$\mathrm{CC}=\frac{\mathrm{sw}_{\text {measured }}}{\text { swWhitman \& Allwine }}$.

The cloud cover was calculated independently for all stations and then averaged to give a single value per day.

\subsection{Vegetation index}

Normalized difference vegetation index (NDVI) is based on the amount of infrared radiation absorbed, which is related to the amount of photosynthesis taking place. It is considered a measure of the density of chlorophyll. NDVI is a ratio of the near-infrared (NIR) to red wavelengths:

$\mathrm{NDVI}=\frac{\mathrm{NIR}-\mathrm{red}}{\mathrm{NIR}+\text { red }}$.

Seasonal change in NDVI was observed by extraction of the area of interest from the $250 \mathrm{~m}$ resolution west Africa eMODIS 10-day temporally smoothed data (USGS FEWS NET). It has been corrected for molecular scattering, ozone absorption, and aerosols, and then smoothed using a least squares linear regression (Swets et al., 1999). The NDVI values are validated with in situ observation and photographs. The pixels that contained our stations were extracted to give a catchment-wide seasonal impression of the vegetation change. All of the pixels that cover our catchment are composed of multiple vegetation types, given the relatively coarse resolution, but they have been sorted by dominant land cover. An inventory of woody species (diameter at breast height of $1.3 \mathrm{~m}$, greater than $10 \mathrm{~cm}$ ), was performed for 1 ha of the savanna forest and the entirety of the agricultural area within the catchment (Table 2). Vegetation was classified according chorology and life form (Adomou, 2005).

\subsection{Wind sector partition}

Dominant wind direction for each half-hour covariance measurement was used to sort the sensible and latent energy 


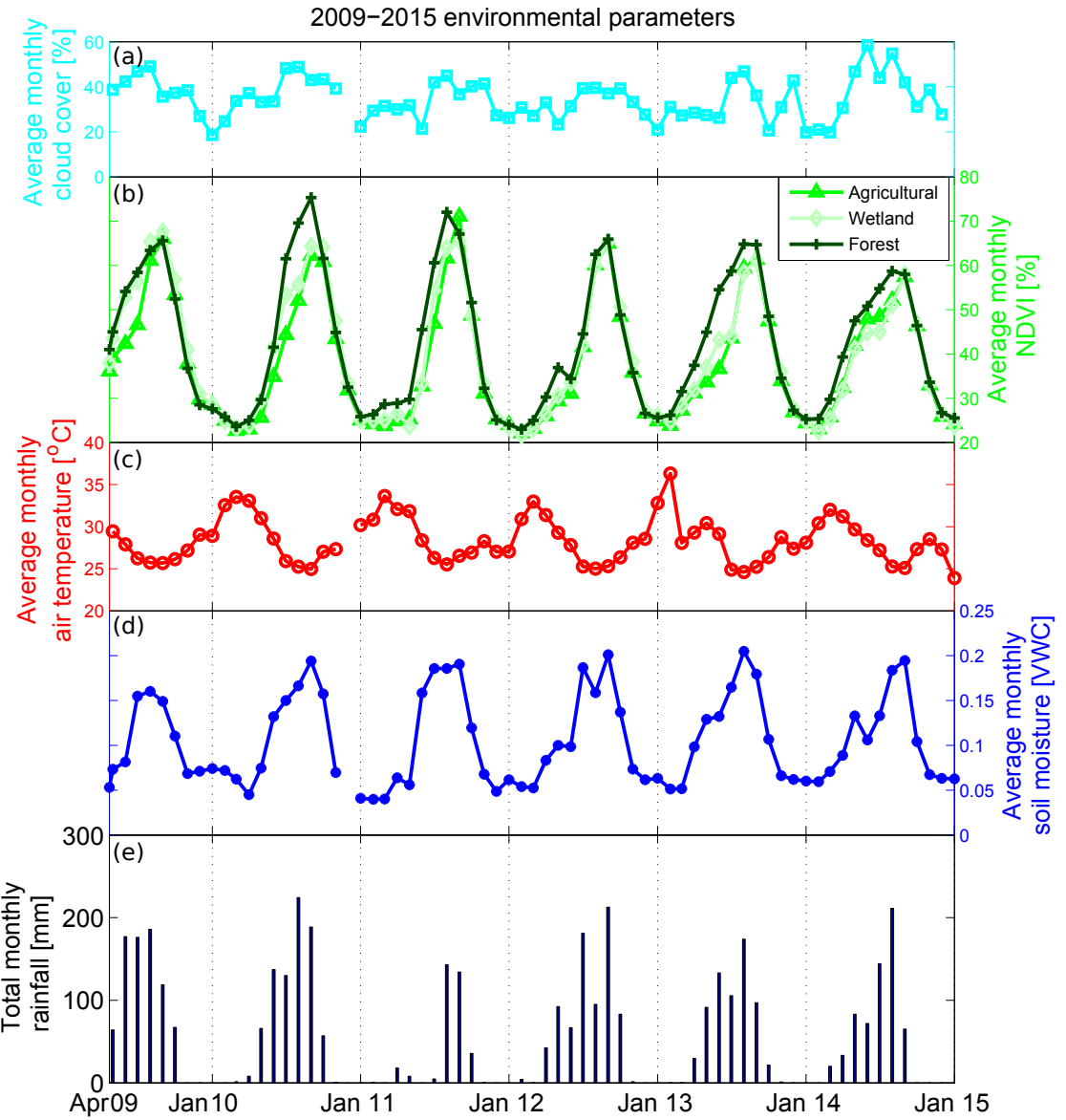

Figure 2. Environmental parameters at the study site for the monitoring period (2009-2015): (a) cloud cover measured with shortwave radiometers and averaged over all stations; (b) average NDVI from MODIS satellite data ( $250 \mathrm{~m}$ resolution, 10-day composite) averaged over each land cover of pixels containing stations; (c) monthly average air temperature (red line), also averaged for all stations; (d) volumetric soil moisture averaged over all stations and all land covers between 5 and $30 \mathrm{~cm}$ depth (blue line); and (e) monthly rainfall (missing bars indicate lack of rain).

fluxes (Fig. 6). Computation of the mean flux according to wind direction allowed for examination of the effect of wind direction, and corresponding land surface, on the flux magnitudes.

\section{Results}

\subsection{Seasonality}

A total of $1600 \mathrm{~mm}$ of precipitation was measured over the period of intensive monitoring (2009-2010) - 789 $\mathrm{mm}$ in 2009 and $811 \mathrm{~mm}$ in 2010 - and it fell almost entirely during the period from May to October. As seen in Fig. 2, average monthly air temperature, cloud cover, soil moisture, and NDVI followed the seasonal cycle of the rain: temperature was higher in the dry season (November-March) than in the wet season (May-October); cloud cover was lower in the dry season and increased starting in March and April peaking both years in July; soil moisture was highest in the wet season; and vegetation, as shown by NDVI, increased over the course of the wet season, starting in May and peaking in September and declining afterwards as grasses senesced. The high level of seasonality is characteristic of semi-arid environments. Separation between the lower and upper parts of the catchment is apparent in the NDVI time series, where the savanna forest consistently stays more green, with the field only surpassing it due to its delayed senescence in September 2010. Plowing, early season harvests, and late season harvests are visible earlier in some years over only the agricultural land. However, since these are averages over a few potentially mixed pixels, which were composed of multiple crops, the individual behaviors are not visible. The land use differentiation is visible even at $250 \mathrm{~m}$ pixel resolution. 
(a)
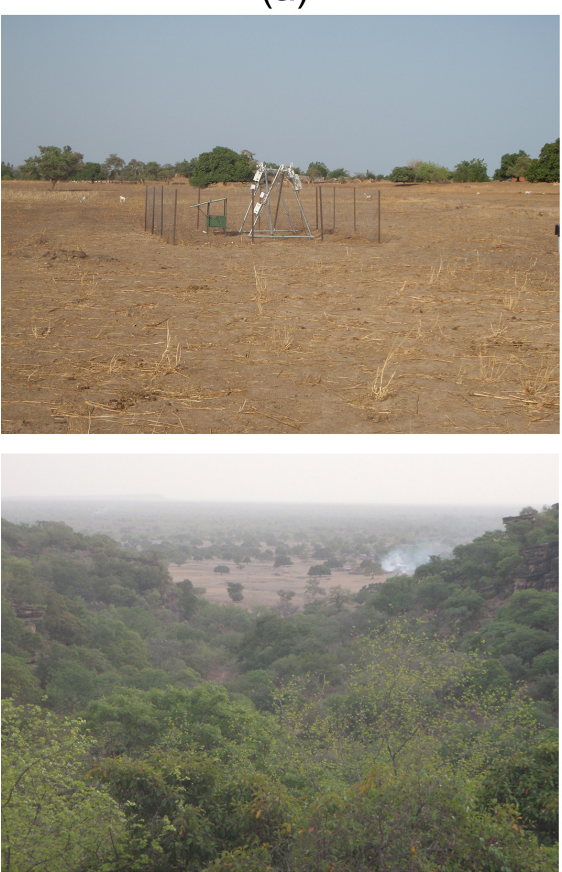

18 Apr 2010

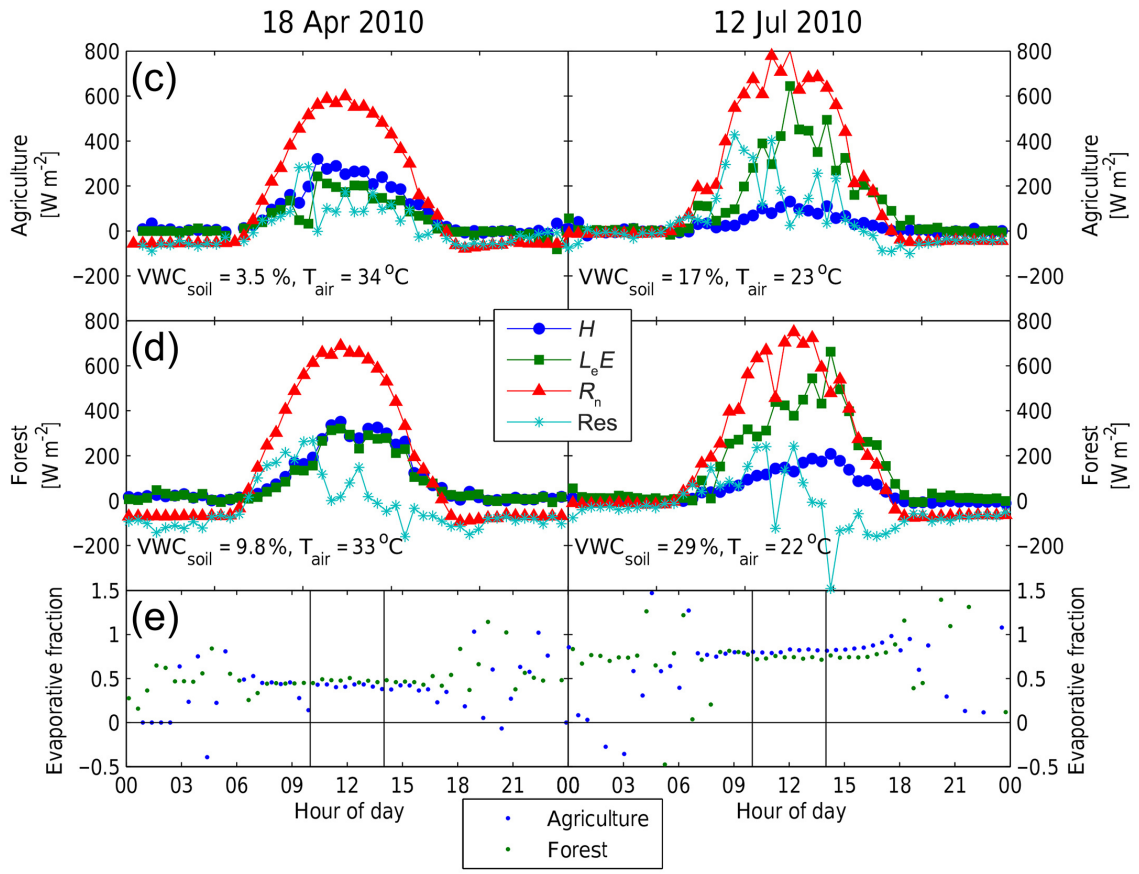

(b)
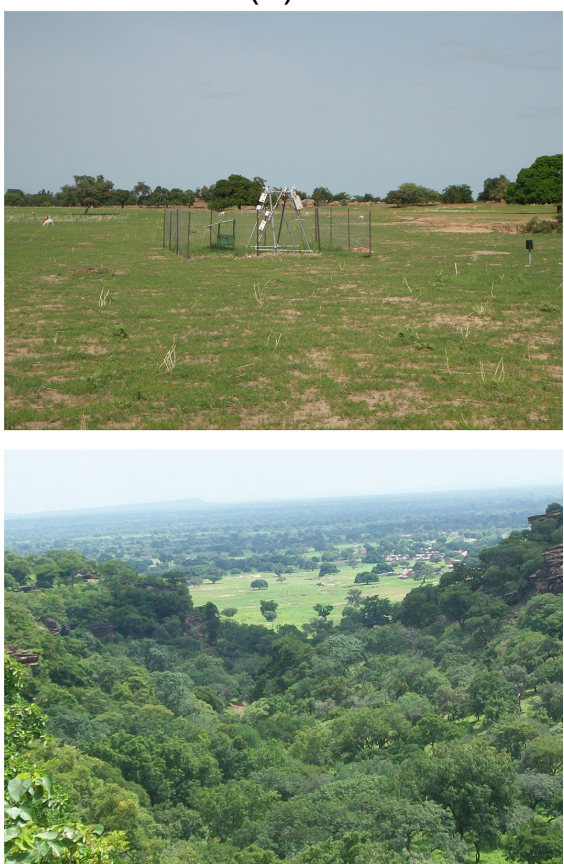

12 Jul 2010

ขึ

Figure 3. The diurnal cycle of the energy balance. The upper four photographs correspond to the four subplots - the date of the photograph is the same month as the representative plot of diurnal energy budget. Note that April (a) was the dry season and the atmosphere was very hazy, in part due to fires. July was the start of the rainy or wet season (b). The energy budget is made up of the sensible heat $(H$, blue), latent heat $\left(L_{\mathrm{e}} E\right.$, green), net radiation $\left(R_{\mathrm{n}}\right.$, red) on the $y$ axis $\left(\mathrm{W} \mathrm{m}^{-2}\right)$ over the savanna forest $(\mathbf{d})$, and agricultural land (c) according to the time of day ( $x$ axis, $24 \mathrm{~h}$ ). The residual of the energy budget is also shown in turquoise. The final row shows the half-hour calculation of evaporative fraction. Daily averages were taken between 10:00 and 14:00 UTC, shown with the vertical lines, with the savanna forest in green and agriculture in blue. 


\subsection{Components of energy balance}

\subsubsection{By day}

The average diurnal cycle of the energy balance varied according to diurnal cycles and by month (Fig. 3). In this figure, we compare a single day in April with a single day in July. The wet season begins after April, and prior to any vegetation growth in the agricultural field, however, some of the evergreen forest canopy is already visible in the photos. By July, crops or fallow are growing in the field and the canopy is greener. This change in vegetation cover and moisture availability is apparent in the diurnal patterns of the energy balance for both sites. Net radiation is slightly higher during the wet season for both land covers, and none of the fluxes are as smooth, which can be explained by the presence of atmospheric humidity and cloud cover. The sensible heat is higher for both land covers in the dry season; however, over the savanna forest, there is still latent flux that nearly matches the sensible heat flux even in the dry season. By July, the latent heat flux surpasses the sensible heat flux for both land covers. This can be explained by moisture availability, as the soil moisture content is much higher in both cases. Over the savanna forest, we can see that the latent heat flux does not decline until the late afternoon, suggesting that it is radiation limited and not moisture limited, whereas over the field it peaks closer to midday. The residual, which is a combination of the ground heat flux and any error, is lower over the savanna forest and is negative in the afternoon. For the month of April, the noon median residual is $20 \%$ of the noon net radiation for the agricultural field and $13 \%$ for the savanna forest, and for the month of July, it is $31 \%$ for the agricultural field and $25 \%$ over the savanna forest. The evaporative fraction is correspondingly higher in the rainy season than in the dry season and, as we would expect, has a higher value over the savanna forest in the dry season but over the agricultural field in the wet season.

Net radiation was the most similar component between the two sites, although during the "dust" season of March and April it was lower over the agricultural field. Sensible heat was greater over the savanna forest for all months, with the greatest difference in the "hot" period of March through May, which is an important period for the triggering of early convective storms.

There is a scale discrepancy between the eddy-covariance measurements and the net radiometer measurements since the latter only senses exchanges directly above and below it, whereas the former's range of detection can span a larger area depending on the wind speed. To account for this, we modeled the net radiation at each small station and then compared it to that measured with net radiometers with acceptable results (see the Supplement).

Latent heat flux was also observed to be greater over the savanna forest compared to the agricultural field. The point in the day when the latent heat flux peaks signals the mo- ment when the system becomes moisture limited; during the early part of the year, the dry season through May, the diurnal cycle of latent heat flux peaked over the agricultural field during the middle of the morning, from 09:00 to 10:00 UTC, whereas over the savanna forest, during the same period, the peak in the diurnal was after noon. In general, our data show that latent heat flux was greatest early in the diurnal cycle during the dry season, which suggests depletion of all available moisture early in the day.

\subsubsection{Over the entire study period}

Time series of turbulent fluxes, soil moisture, normalized difference vegetation index, and rainfall demonstrate the highly seasonal moisture and energy availability (Fig. 4). A high correlation exists for net radiation and the sum of turbulent fluxes (Fig. 5) between the savanna forest and the field, with more scatter occurring when soil was wetter (blue). However, the sum of the turbulent fluxes is higher over the savanna forest than over the field. Since there are equal amounts of net radiation, we can deduce that there is a greater ground heat flux in the field. The lack of shading in the field, and the greater abundance of trees, with a high level of productivity, and rocks support this observation. Examination of the two components of net radiation - net longwave and net shortwave - shows that soil moisture exerts much greater control on net longwave radiation, with the change in net longwave radiation according to changes in soil moisture in the field much more apparent. Although there is more scatter in net shortwave when soil is wetter, it is less uniformly a response to the two land covers. The savanna forest's net longwave radiation is greater when the soil is dry, whereas the agricultural area has greater net longwave radiation when it is wet. Sensible heat over all land covers is greater under dry conditions than wet (blue), but both sensible and latent heat fluxes are greater over the savanna forest than over the agricultural field regardless of soil moisture.

Furthermore, in Fig. 6, we see that each wind sector has a distinct signature of when latent heat flux is greater than sensible heat flux. This variation can be explained because certain features, such as the ephemeral wetland and the gallery forest (shown in the top left of the forest plot, $16-46^{\circ}$ ), contributed to higher fluxes that have access to moisture that persists longer into the dry season. Over the agricultural field, there is more scatter, whereas over the savanna forest, there is a minimal level of about $-170 \mathrm{~W} \mathrm{~m}^{-2}$ for net longwave radiation. In this case, the tree canopy buffers the bare ground from the radiation loss.

\subsubsection{Month by month}

Figure 7 shows the two contrasting trends in surface heat fluxes by comparison of the month-by-month ratios between the measurements over the savanna forest and agricultural land. The savanna forest contributed more sensible and latent 


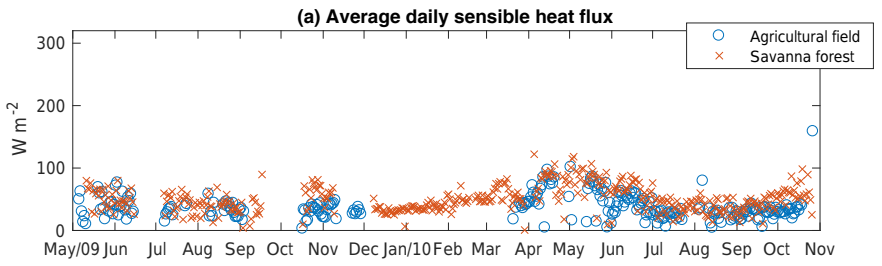

(b) Average daily latent heat flux

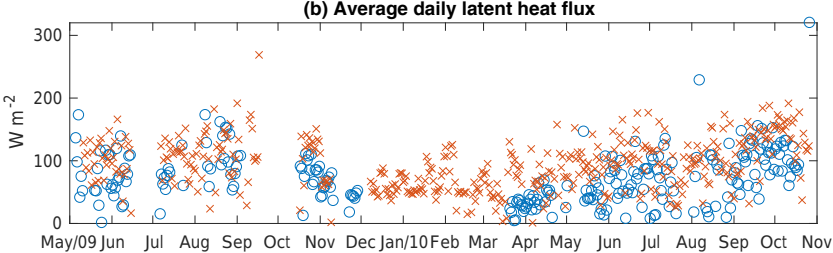

(c) Average daily net radiation

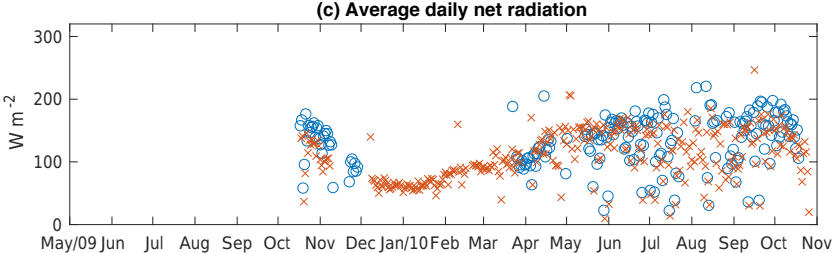

(d) Average daily residual
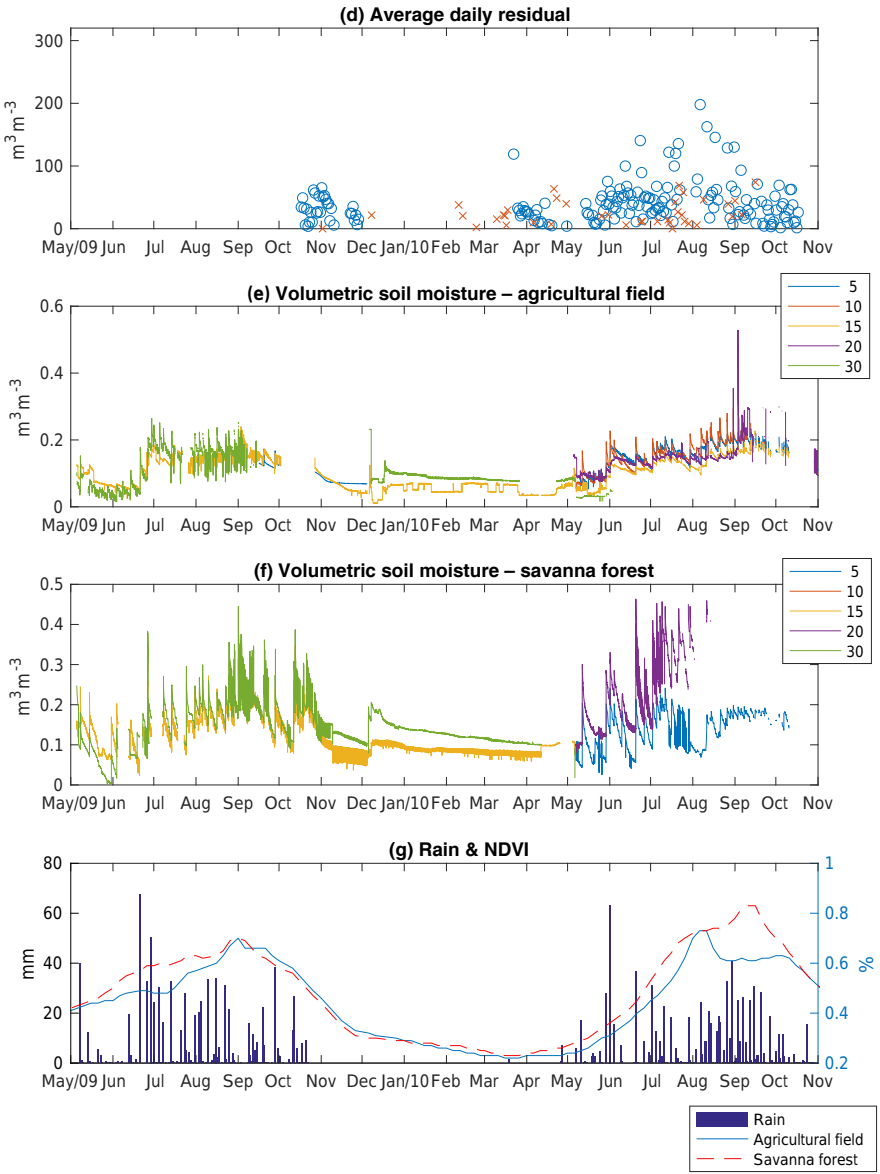

Figure 4. Time series of average daily sensible heat flux (a), average daily latent heat flux (b), average daily net radiation (c), average daily residual (d), volumetric soil moisture in the agricultural field (e), volumetric soil moisture in the savanna forest (f), and daily rain and NDVI (g). Panels (a-d) show the data from the energy balance stations over the agricultural field (blue circles) and savanna forest (red crosses) in watts per square meter. Panels (e-f) show the volumetric soil moisture at five different depths over the same time period. Finally, panel (g) shows the NDVI for the pixels containing the energy balance station in the field (blue dashed) and in the savanna forest (red, solid). The daily rain in millimeters is shown as a bar graph. 

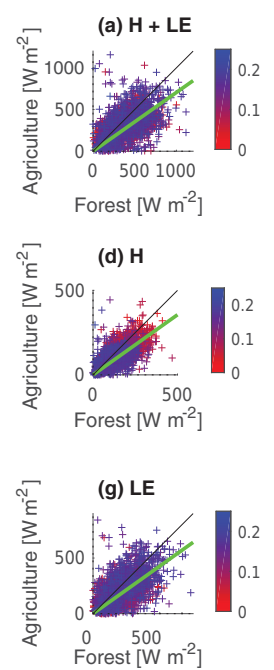
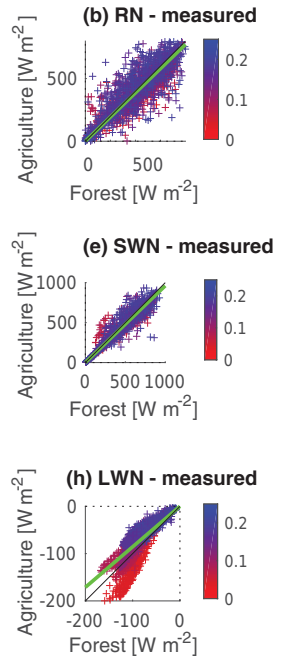
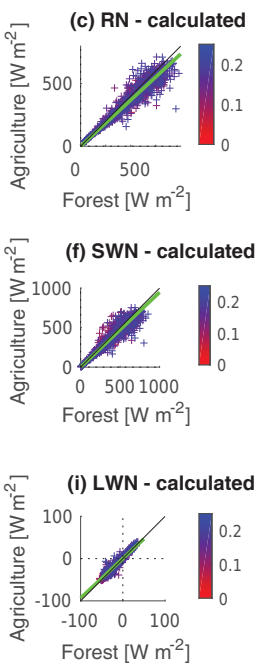

Figure 5. Comparison between fluxes measured over the savanna forest and the field. In each plot, the color indicates soil volumetric water content: red is dry and blue is wet. The least squares regression lines are shown in green and the $1: 1$ lines are in black. Measurements over the savanna forest are on the $x$ axis and those over agriculture are on the $y$ axis. All fits were significant $(p<0.005)$. Panels $(\mathbf{b}, \mathbf{e}, \mathbf{h})$ show the components of net radiation calculated with the net radiometers. Panels $(\mathbf{c}, \mathbf{f}, \mathbf{i})$ show the components of net radiation calculated using parameters measured at the small meteorological stations: air temperature (Ta), incoming shortwave radiation (SW), and soil temperature (Ts); see the Supplement.

heat fluxes throughout the year (ratio less than 1), but the difference in sensible heat flux between the two sites was greatest at the end of the year, the beginning of the dry season, and the difference latent heat flux between the two sites was greatest at the beginning of the year, after land was cleared by burning. These trends were consistent over the 2 years of measurement; however, there were some months (July and August 2010) when the sensible heat was close to equal in the two sites. The higher level of similarity in sensible heat between the two sites in 2009 can be explained by the crop choice that year; that field was planted with early (6095 days) maturing pearl millet crop compared to its usual late variety (130-150 days), requiring a unusually late tilling and an unusually early harvesting, resulting in bare ground during the growing season. These differences are also visible in the NDVI (Figs. 2 and 4). Net radiation was more similar than the other fluxes; the greatest difference occurred when there was bare ground in the field, at end of the dry season, suggesting a higher albedo during this time.

\subsection{Evaporative fraction}

\subsubsection{Correlations with surface and atmospheric conditions}

Examination of the relationship between evaporation and the environmental variables that dominate in various models shows that, for our site, soil moisture and vegetation cover have the strongest positive correlation with evaporative fraction (Fig. 8). Over both the savanna forest and the field, we see that landscape moisture availability, expressed as both NDVI and soil moisture (VWC), exert a strong influence on the evaporative fraction, with higher rates of evaporation occurring at higher levels of soil moisture and vegetation cover or, in other words, moisture availability from either plant or soil. Total net radiation does not show a strong influence, suggesting that this is not a radiation-limited system.

Wind speed shows a strong negative correlation with more evaporation occurring at lower wind speeds, contrary to standard evaporation models. Evaporative fraction and the cloud cover exhibit a positive correlation both over the field and the savanna forest and could be explained by a two-part discontinuous function, with a break at 0.4 (Brutsaert, 1982). In a radiation-limited system, cloud cover would reduce evaporative fraction, but in this case, since it is positive, we can deduce that cloud cover is an indicator of high rates of evaporation and moisture availability, thus further supporting our hypothesis that this is a moisture-limited system.

\subsubsection{Explanatory model}

The relationship between soil moisture, vegetation index, and evaporative fraction can be fitted with a linear regression (Fig. 9):

$\left\{\begin{array}{l}\mathrm{EF}_{\text {agriculture }}=0.41 \times \mathrm{NDVI}+1.4 \times \mathrm{VWC}+0.27 \\ \mathrm{EF}_{\text {savanna forest }}=0.48 \times \mathrm{NDVI}+0.35 \times \mathrm{VWC}+0.34 .\end{array}\right.$

Evaporative fraction depends on both soil moisture and vegetation index over agriculture, whereas over the savanna forest it responds more directly to vegetation index, as shown by the direction of the evaporative fraction color gradient. The evaporative fraction is more variable over the agricultural field, explaining the less good fit of the regression $\left(R^{2}=59 \%\right)$ compared to that over the savanna forest $\left(R^{2}=66 \%\right)$. Inclusion of net radiation, cloud cover, downwelling radiation, and wind speed in this model did not significantly change the quality of the regression. This further supports our understanding that this is a moisture-limited system. This linear regression model provides an estimation that confirms our understanding of the physical basis of the fluxes. 

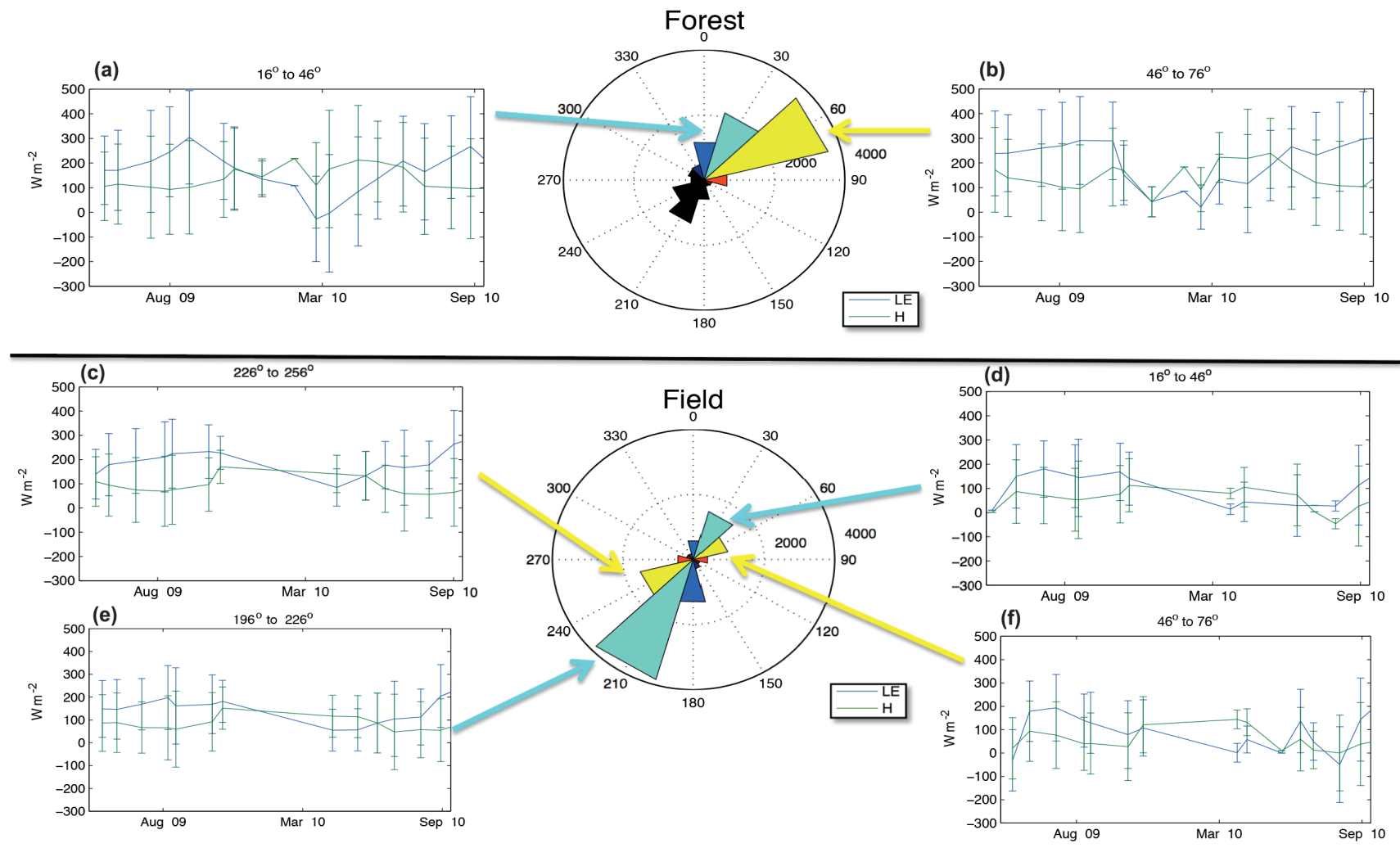

Figure 6. Two dominant wind sectors for each eddy-covariance setup are plotted: over the savanna forest (a, b) and over the agricultural field (c-f). Mean latent heat flux for each month with standard deviations is shown in blue and sensible heat in green. Note that for some months there were no data.

\section{Discussion}

\subsection{Energy balance}

The most striking observation is that the savanna forest had consistently higher levels of both sensible and latent heat fluxes across all months (Figs. 4 and 5). Sensible heat fluxes over the two surfaces showed the greatest difference in November and October (Fig. 6). Latent heat flux is the most different between the two land uses in August and May, which are transition times when the access to water in the catchment is not uniform (Fig. 6). The greatest similarity between the two land covers was during the wet season (May through September). The difference between the energy balance of the two sites was the most accentuated in the transition from the wet to dry season that occurred in the month of October for sensible heat flux and in the early wet season for latent heat flux (Figs. 4, 5, and 7). Because of this observation, we can expect land use changes to have the most impact during these transition periods, due to differences in growth patterns and rooting depths. In particular, since agricultural crops are planted, their germination and development is determined by agricultural decisions above water and energy availability. The behavior during the growing season from June through August varied so dramatically between 2009 and 2010 because in 2009 short season millet was planted, whereas in 2010, it was left fallow. We can imagine that this difference is due to the high growth rates of the agricultural crop through August and the subsequent harvest, whereas the fallow crops grow quickly, transpiring the most in July and then stabilizing into August (Fig. 4). The sensible and latent energy fluxes from the fallow were lower than those of the forest in 2010, whereas when short season millet was growing, they were more similar. By comparing the changes in soil moisture along the diurnal cycle, we see that even in the dry season there is some variation, particularly at shallow depths; thus, in contrast to other authors, we cannot attribute the early peak purely to stomata behavior during the dry season (Mamadou et al., 2016). In contrast, during the rainy season, it declined, following the cycle of available radiation.

The net radiation was very similar over both land surfaces, with the greatest differences occurring in the dry season. However, early in the dry season, net radiation was higher over the agricultural field, whereas early in the dry season, it was higher over savanna forest. This second counter-intuitive finding is supported by other work in the subregion that found that net radiation was higher over woody vegetation during the dry season and explained the difference because 

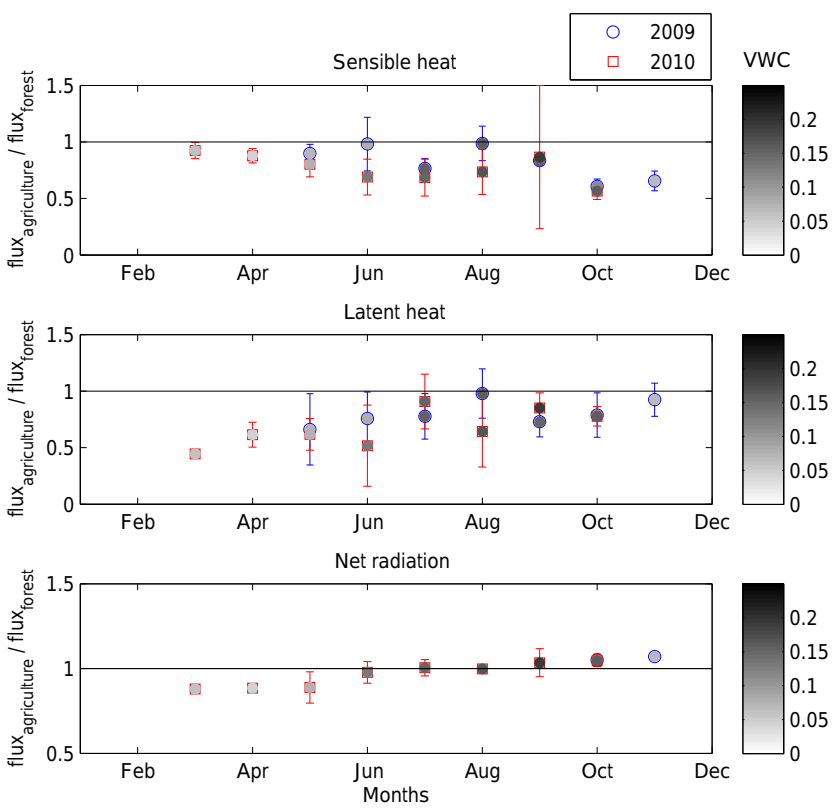

Figure 7. Examination of ratio of the daily fluxes by month and year. The ratios between flux measurements over the field and savanna forest are shown according to the month ( $x$ axis) and year (in color: blue indicates 2009 and red indicates 2010). The soil moisture value is shown with shading. Error bars show the standard deviation around the average of daily ratios. Points below the 1 line indicate when the savanna-forest flux is higher than the agricultural field flux. It is important to note that the field was farmed in 2009 until the end of July but left fallow in 2010 .

surface temperature was lower and net longwave radiation was higher (Guyot et al., 2009). The residual of the energy budget showed fewer clear patterns, but across seasons, it was greater over the field, likely due to larger ground heat flux into the bare soil.

Two contrasting trends explain why the sensible heat fluxes becomes less similar as the year progresses, whereas the latent heat fluxes becomes more similar. First, at the start of the year, the agricultural field is covered with bare ground and the rocks are exposed above the forested area, and throughout the growing season, the bare ground is progressively covered with grass, whereas on the hill, the rocks remain exposed. At the end of the wet season, the grass senesces and remains until it is burned in late December or January. The contrast of the annual cycles of bare ground and bare rock drives the difference in sensible heat flux. The bare ground has a high level of albedo compared to the rocks, creating a difference in available energy for turbulent fluxes.

Second, at the start of the year, the upper trees have access to water coming from the springs at the base of the rocks. Although the level of water availability and vegetation increases during the wet season and declines during the following dry season, the spring is permanent perhaps due to subsurface lateral water transfer that also produces shallow groundwater that is available to the trees (Mande, 2014). In contrast, the water availability in the field and the corresponding greenness closely follow the annual cycle of precipitation, driving the variation in latent heat. The ephemeral stream stops flowing at the end of December, when the grasses dry up and the latent heat flux returns to being drastically different between the two sites (Mande, 2014).

Our observations of $H$ and $L_{\mathrm{e}} E$ are higher than fluxes previously measured in the region (Bagayoko et al., 2007; Dolman et al., 1997; Gash et al., 1997; Guichard et al., 2009; Guyot et al., 2009; Mauder et al., 2006; Schüttemeyer et al., 2006; Timouk et al., 2009), which can be explained by our site's location inside a semi-protected area with regionally relative high amount of vegetation, increasing $L_{\mathrm{e}} E$, and an abundance of rocks, raising $H$. Furthermore, annual cycles of ratios between $H$ and $L_{\mathrm{e}} E$ vary by wind sector (Fig. 6), demonstrating that small variations in land cover, topography, and moisture availability can lead to dramatic differences in evaporation and evaporative fraction. This is consistent with local land management philosophy, which emphasizes the importance of maintaining the gallery forest, and springs therein, as a common moisture reservoir in the dry season and in the case of drought. More continuous, longterm measurements during extreme years would reinforce the validity of this local belief. Our results also emphasize that the forest, even though it is primarily an open wooded savanna, has a higher level of productivity than the rain-fed, hand-farmed fields.

Our values of sensible and latent heat fluxes are most similar to those measured in Ejura, Ghana, in 2002 (Schüttemeyer et al., 2006). Ejura is about $500 \mathrm{~km}$ from our site, and though quite far and typically placed in a different category of climate, we measure similar values compared to other areas of west Africa (Guyot et al., 2009), perhaps because measurements took place in November, when vegetation there would be most similar to that at our site. Kompienga is the most similar site and is closest to ours; though measurements display the same seasonality as those at our site, they are still lower than ours (Bagayoko et al., 2007). The scale incongruity between the turbulent flux (sensible and latent) measurements and the net radiation may explain our lack of closure instead of, for example, surface heat water storage during floods (Guyot et al., 2009). There is a strong topographic difference close to the forested area; however, we are confident that our planar fit correction effectively corrected for the corresponding effect on turbulent fluxes.

The high magnitude of turbulent fluxes can be explained by Tambarga-Madjoari's location in the midst of a natural park and hunting concession as well as our measurement of a gallery forest, which would demonstrate the importance of the nearby vegetation cover. On the whole, our measurements are comparable to those elsewhere in west Africa, given that most of these sites (Mali, Niger) are more Sahelian, and thus have less moisture availability, and others (Nigeria, Benin, 

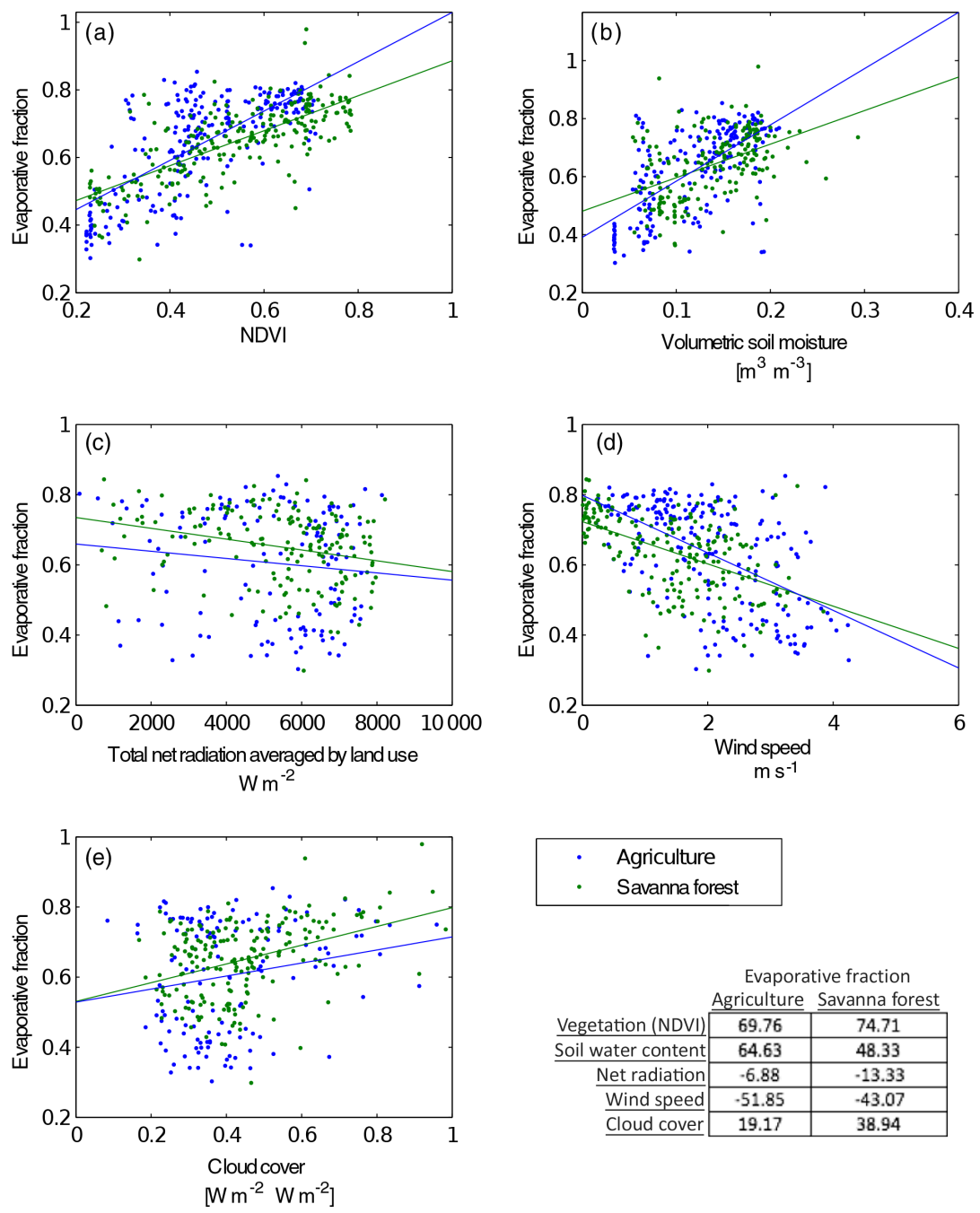

Figure 8. Daily evaporative fraction over study period for the agricultural field (blue) and the savanna forest (green) compared with the observed (a) NDVI, (b) VWC, (c) wind speed, (d) net radiation, and (e) cloud cover. In all cases, environmental variables are from the average of stations with the same land cover with the energy balance station. These plots show a better correlation with NDVI and VWC (a, b), suggesting a moisture-limited and not a radiation-limited system. The least squares regression lines are shown for each plot. Correlations between variables are in the table.

Ghana) are considerably further south and thus have denser vegetation (White, 1986).

\subsection{Evaporative fraction}

The median monthly evaporative fraction in the savanna forest was lowest in April at 0.47 and highest in September at 0.77 , and for the agricultural fields, it was also lowest in April at 0.31 and highest in September at 0.79. These values are in general higher than previously found in similar environments during the rainy season (Bagayoko et al., 2007; Brümmer et al., 2008; Guyot et al., 2012; Mamadou et al., 2016). In contrast, our site has a lower dry season evaporative fraction than nearby sites, which suggests that moisture cycling during the wet season is more complete and that there is less storage into the dry season. This is likely due to a combination of vegetation, soil, and topographic characteristics.

We can compare our values of evaporative fraction with other environmental conditions. Over west Africa, the selfpreservation concept of the evaporative fraction could be used together with variables such as albedo, temperature at the surface, and a vegetation index to obtain a reasonable estimate of evaporation (Compaore, 2006). A high correlation between midday evaporation and the evaporative fraction exists in Kenyan grasslands (Farah et al., 2004). Evaporative fraction might be affected by cloud cover which alters incoming radiation (Brutsaert and Sugita, 1992); however, cloudiness was not related to the stability of evaporative fraction in 2005-2006 in Brazil (Santos et al., 2010). Evaporative fraction may also be related to other environmental param- 

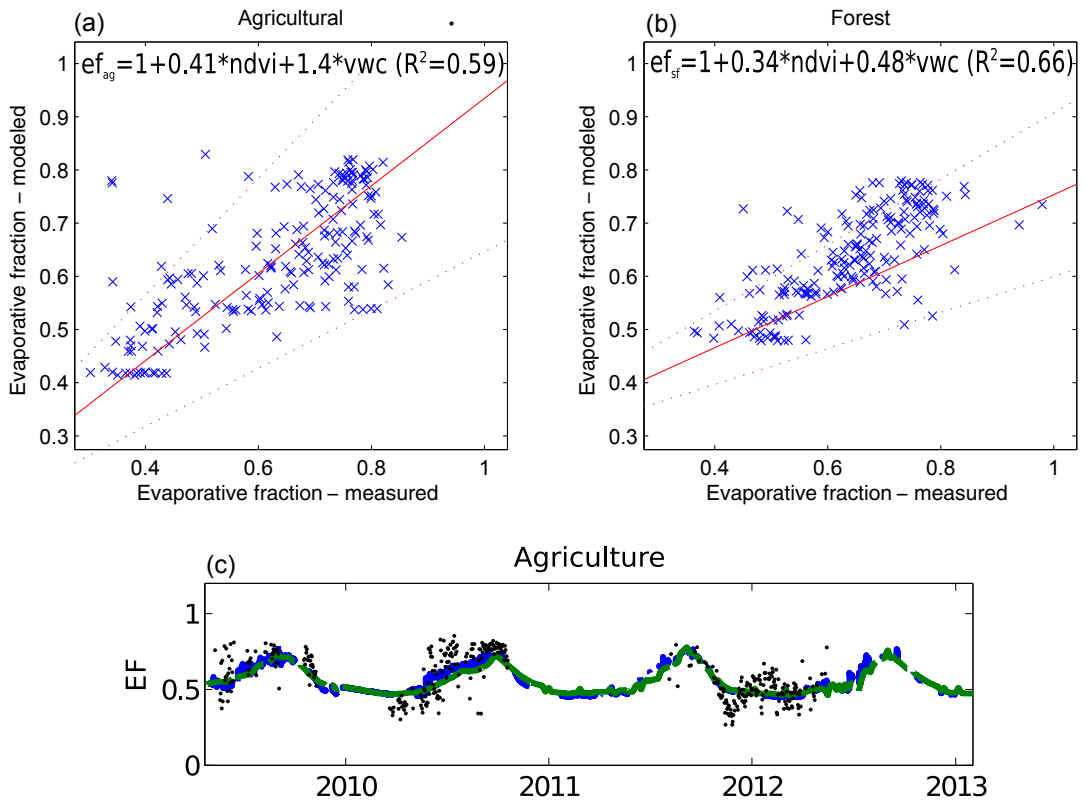

(d) Savanna forest

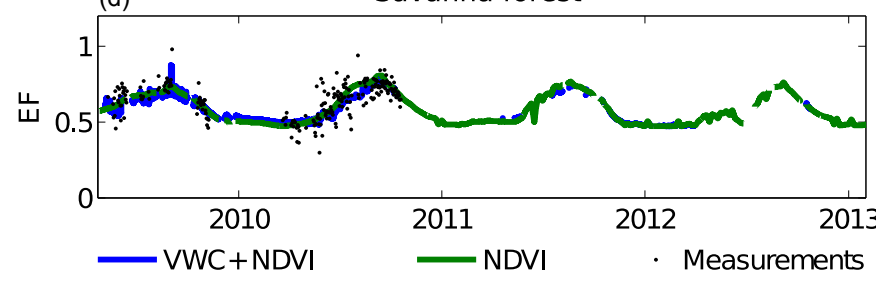

Figure 9. Further examination of relationship between soil moisture, vegetation index, and evaporative fraction. Panels (a, b) show the quality of fit of the linear regression model relating soil volumetric water content, vegetation index, and evaporative fraction over agriculture (a) and over the savanna forest (b). The 1: 1 line is in red and the $95 \%$ confidence interval is shown with dotted lines for the range of available soil and vegetation. Evaporative fraction over the field (b) and the savanna forest (d) are shown. Measured data points are in black (points), calculated evaporative fraction based on soil moisture and NDVI are shown in blue, and NDVI alone is shown in green.

eters that are increasingly available and reliable, which are obtained remotely through satellites, such as soil moisture (Crago, 1996; Hall et al., 1992). One limitation of this approach is that of the temporal scale since evaporative fraction is computed by day but surface conditions and moisture availability can change instantaneously. However, it is extremely valuable to be able to estimate evaporative fraction when only NDVI or other remotely sensed parameters are available. For this reason, our estimation of evaporative fraction with a simple model based on the physical basis of fluxes linked to vegetation and soil moisture is useful (Fig. 9). This model can be refined with longer and more varied datasets to increase its accuracy and suitability regionally.

\subsection{Social context}

The gallery forest over which we measure fluxes includes two springs that were the main water source for the village at its founding until a generation ago (Ceperley, 2014). Its important role in local history means that special institutions ex- isted in local tradition for its conservation. For example, wetlands and other areas with abundant water, fall into a Gourmantché category for land called "Tinjali" or land that was not farmed because of cultural taboos until recent development projects and the introduction of rice farming (Swanson, 1978). In addition, since it is forested, it is protected because Gourmantché believe that trees have spirits, which may prohibit them from being cut or used, and that some are considered good and some bad. So it is reasonable to conclude that the presence of the forest is not only because the water availability provides the habitat but also because the village has protected it on some level. Additionally, it is reasonable to think that the institutions that protect this forest are not only protecting it but also the ecosystem services that it preserves. Our work suggests that these ecosystem services include the cycling of moisture into the atmosphere and the eventual generation of rainfall. In this light, the Gourmantché myth explains that there is a sack of water above the atmosphere that spirits can pierce, bringing rain delivered by clouds (Alves, 2012). If the gods pierced those clouds with "trees", then our 
research seems to be right on target in terms of validating what traditions have long known. This is an important tool: as land use becomes more and more contested, the validation of local institutions or land uses can ensure the continuation of these practices.

\section{Conclusions}

Sensible and latent heat fluxes were higher over a savanna forest than a semi-cultivated (millet-fallow) field according to our measurements in a Sudanian ecosystem of west Africa in 2009 and 2010. The sensible heat and latent heat flux are generally higher over the savanna forest because of its more permanent water availability and corresponding greenness, higher productivity, and the amount of rocky terrain. For example, the diurnal cycle of latent heat flux peaked earlier in the day during the dry season in the agricultural field, suggesting depletion of all available moisture by late morning. These observations of sensible and latent heat fluxes are higher than fluxes previously measured in the region, potentially due to this site's location inside of a semi-protected area. Analysis of wind sectors separately revealed that particular sectors, corresponding to the location of particular features, for example, over the ephemeral wetland and the gallery forest, contributed higher amounts to the flux. Local land management emphasizes the importance of maintaining the gallery forest, and springs therein, as a common humidity reservoir in the dry season and in the case of drought. Changes in land cover may even have consequences for local rainfall triggering, causing cascading effects that transform both the energy and water budgets.

Continuous, long-term measurements during drought and moist years are essential to prove the long-term validity of our observations. Additionally, variations in exchanges according to small landscape features could result in enormous underestimation for upscaling. We recommend using eddycovariance measurements such as these to improve estimates with more easily maintained and obtained meteorological station and satellite data. The evaporative fraction is dependent on NDVI, which is an important finding for modeling and upscaling. Efforts focused on preserving hydrologic services need to take anomalies into account and reinforce cultural institutions that protect wetlands and gallery forests.

The development of a simple NDVI-based indicator of evaporative fraction is transferable to other semi-arid systems, agroforestry parklands, and open wooded savannas around the globe. Globally, the African continent and often semi-arid environments represent a gap in observations of land-atmosphere interactions. This study is an important step in filling this gap and proposing a tool with still greater potential.

Our results point to the necessity for ground measurements for eventual upscaling from point to regional evaporation measurements in remote and less-studied regions of the globe. We began this work with discussion with community partners and, to bring it full circle, we conclude this paper by relating it back to the cultural context.

Data availability. All data for this research are available at https://doi.org/10.4121/uuid:0dbbaf01-bea4-4520-aee9c3ebd354b27c (Ceperley et al., 2017) via the 4TU Centre for Research Data (https://data.4tu.nl).

\section{The Supplement related to this article is available online at https://doi.org/10.5194/hess-21-4149-2017- supplement.}

Competing interests. The authors declare that they have no conflict of interest.

Special issue statement. This article is part of the special issue "Observations and modeling of land surface water and energy exchanges across scales: special issue in Honor of Eric F. Wood". It is a result of the Symposium in Honor of Eric F. Wood: Observations and Modeling across Scales, Princeton, New Jersey, USA, 2-3 June 2016.

Acknowledgements. The Velux and 3rd Millennium foundations funded a large part of this research, in addition to support from the young researcher's (KFPE) grant from the Swiss Agency for Development and Cooperation. Alexandre Repetti, Jean-Claude Bolay, and the center for cooperation at EPFL initiated and continued to this project. We would like to thank all of our colleagues, assistants, and students based both in Switzerland and in Burkina Faso who helped us with fieldwork. In particular, collaboration with the International Institute of Environment and Water Engineering facilitated this research. We give additional gratitude to the commune of Madjoari, its residents, and its government, who hosted us and our equipment for the duration of this project. The manuscript was greatly improved by feedback from reviewers and the scientific community; for that, we are grateful. The final analysis was completed with the support of the NSERC discovery grant.

Edited by: Reed Maxwell

Reviewed by: two anonymous referees

\section{References}

Abiodun, B. J., Pal, J. S., Afiesimama, E. A., Gutowski, W. J., and Adedoyin, A.: Simulation of West African monsoon using RegCM3 Part II: impacts of deforestation and desertification, Theor. Appl. Climatol., 93, 245-261, 2008.

Adomou, A.: Vegetation patterns and environmental gradients in Benin, $\mathrm{PhD}$ thesis, Wageningen University, Wageningen, the Netherlands, 2005. 
Alves, J. P. G.: Anthropologie et écosystèmes au Niger: humains, lions et esprits de la forêt dans la culture gourmantché, Editions Harmattan, Paris, France, 448 pp., 2012.

Arbonnier, M.: Trees, Shrubs and lianas of West African dry Zones, CIRAD, MNHN, Montpellier, France, 2004.

Aubinet, M., Feigenwinter, C., Heinesch, B., Laffineur, Q., Papale, D., Reichstein, M., Rinne, J., and Gorsel, E. V.: Nighttime Flux Correction, in: Eddy Covariance, edited by: Aubinet, M., Vesala, T., and Papale, D., Springer Netherlands, 133-157, https://doi.org/10.1007/978-94-007-2351-1, 2012.

Bagayoko, F., Yonkeu, S., Elbers, J., and van de Giesen, N.: Energy partitioning over the West African savanna: Multi-year evaporation and surface conductance measurements in Eastern Burkina Faso, J. Hydrol., 334, 545-559, https://doi.org/10.1016/j.jhydrol.2006.10.035, 2007.

Bateni, S. M. and Entekhabi, D.: Relative efficiency of land surface enrgy balance components, Water Resour. Res., 48, W04510, https://doi.org/10.1029/2011WR011357, 2012.

Bordes, C.: La Gestion Des Arbres Par Les Paysans: Etude d'une enclave au milieu de reserves forestieres au sud-est du Burkina Faso, Ingenieur, ISTOM, Cergy-Pontoise, France, 2010.

Brümmer, C., Falk, U., Papen, H., Szarzynski, J., Wassmann, R., and Brüggemann, N.: Diurnal, seasonal, and interannual variation in carbon dioxide and energy exchange in shrub savanna in Burkina Faso (West Africa), J. Geophys. Res., 113, 1-11, https://doi.org/10.1029/2007JG000583, 2008.

Brutsaert, W.: Evaporation into the Atmosphere: Theory, History, and Applications, Kluwer Academic Publishers, Dordrecht, the Netherlands, 1982.

Brutsaert, W. and Parlange, M. B.: The Unstable Surface Layer Above the Forest: Regional Evaporation and Heat Flux, Water Resour. Res., 28, 3129-3134, 1992.

Brutsaert, W. and Sugita, M.: Application of Self-Preservation in the Diurnal Evolution of the Surface Energy Budget to Determine Daily Evaporation, J. Geophys. Res., 97, 18377-18382, 1992.

Burba, G.: Eddy Covariance Method for Scientific, Industrial, Agricultural and Regulatory Applications, Li-COR Biosciences, Lincoln, Nebraska, USA, 2005.

Burba, G.: Eddy Covariance Method for Scientific, Industrial, Agricultural and Regulatory Applications: A Field Book on Measuring Ecosystem Gas Exchange and Areal Emission Rates, LI-Cor Biosciences, Lincoln, Nebraska, USA, 2013.

Ceperley, N. C.: Ecohydrology of a Mixed Savanna-Agricultural Catchment in South-East Burkina Faso, West Africa, Swiss Federal Institute of Technology, Lausanne, available at: http:// infoscience.epfl.ch/record/195232/files/EPFL_TH6040.pdf (last access: 5 February 2015), 2014.

Ceperley, N. C., Mande, T., Parlange, M. B., Tyler, S., van de Giesen, N., and Yacouba, H.: Energy Balance, Tambarga, Burkina Faso, 2009-2010, https://doi.org/10.4121/uuid:0dbbaf01bea4-4520-aee9-c3ebd354b27c, 2017.

Charney, J. G.: Dynamics of deserts and drought in the Sahel, Q. J. Roy. Meteor. Soc., 101, 193-202, 1975.

Compaore, H.: The impact of savannah vegetation on the spatial and temporal variation of the actual evapotranspiration in the Volta Basin, Navrongo, Upper East Ghana, Ecol. Dev. Ser., edited by: Denich, M., Martius, C., Rogers, C., van de Giesen, N., and Compaoré, H., Cuvillier Verlag, Göttingen, Germany, 1-144, 2006.
Crago, R. D.: Conservation and variability of the evaporative fraction during the daytime, J. Hydrol., 180, 173-194, https://doi.org/10.1016/0022-1694(95)02903-6, 1996.

Crago, R. D. and Qualls, R.: The value of intuitive concepts in evaporation research, Water Resour. Res., 49, 6100-6104, https://doi.org/10.1002/wrcr.20420, 2013.

Dolman, A. J., Gash, J. H. C., Goutorbe, J.-P., Kerr, Y., Lebel, T., Prince, S. D., and Stricker, J. N. M.: The role of the land surface in Sahelian climate: HAPEX-Sahel results and future research needs, J. Hydrol., 188-189, 1067-1079, https://doi.org/10.1016/S0022-1694(96)03183-6, 1997.

Domingo, F., Serrano-Ortiz, P., Were, A., Villagarcía, L., García, M., Ramírez, D. A., Kowalski, A. S., Moro, M. J., Rey, A., and Oyonarte, C.: Carbon and water exchange in semiarid ecosystems in SE Spain, J. Arid Environ., 75, 1271-1281, https://doi.org/10.1016/j.jaridenv.2011.06.018, 2011.

Ezzahar, J., Chehbouni, A., Hoedjes, J., Ramier, D., Boulain, N., Boubkraoui, S., Cappelaere, B., Descroix, L., Mougenot, B., and Timouk, F.: Combining scintillometer measurements and an aggregation scheme to estimate area-averaged latent heat flux during the AMMA experiment, J. Hydrol., 375, 217-226, https://doi.org/10.1016/j.jhydrol.2009.01.010, 2009.

Farah, H. O., Bastiaanssen, W. G. M., and Feddes, R. A.: Evaluation of the temporal variability of the evaporative fraction in a tropical watershed, Int. J. Appl. Earth Obs., 5, 129-140, https://doi.org/10.1016/j.jag.2004.01.003, 2004.

Farhadi, L.: Estimation of Land Surface Water and Energy Balance Flux Components and Closure Relation Using Conditional Sampling, MIT, Cambridge, Mass., USA, 2012.

Feddema, J. J., Oleson, K. W., Bonan, G. B., Mearns, L. O., Buja, L. E., Meehl, G. A., and Washington, W. M.: The importance of land-cover change in simulating future climates, Science, 310, 1674-1678, https://doi.org/10.1126/science.1118160, 2005.

Federer, C. A., Vörösmarty, C., Fekete, B., and Olume, V.: Sensitivity of Annual Evaporation to Soil and Root Properties in Two Models of Contrasting Complexity, J. Hydrometeorol., 4, 1276-1290, https://doi.org/10.1175/15257541(2003)004<1276:SOAETS>2.0.CO;2, 2003.

Foken, T.: The energy balance closure problem: An overview, Ecol. Appl., 18, 1351-1367, https://doi.org/10.1890/06-0922.1, 2008.

Foken, T., Mauder, M., Liebethal, C., Wimmer, F., Beyrich, F., Leps, J.-P., Raasch, S., DeBruin, H. A. R., Meijninger, W. M. L., and Bange, J.: Energy balance closure for the LITFASS-2003 experiment, Theor. Appl. Climatol., 101, 149160, https://doi.org/10.1007/s00704-009-0216-8, 2009.

Foken, T., Leuning, R., Oncley, S. R., Mauder, M., and Aubinet, M.: Corrections and Data Quality Control, in: Eddy Covariance: A Practical Guide to Measurement and Data Analysis, edited by: Aubinet, M., Vesala, T., Papale, D., Springer Atmospheric Sciences, https://doi.org/10.1007/978-94-007-2351-1, 2012.

Gash, J. H., Kabat, P., Monteny, B. A., Amadou, M., Bessemoulin, P., Billing, H., Blyth, E. M., Elbers, J. A., Friborg, T., Harrison, G., and Holwill, C. J. T.: The variability of evaporation during the HAPEX-Sahel intensive observation period, J. Hydrol., 188, 385-399, 1997.

Gentine, P., Entekhabi, D., Chehbouni, A., Boulet, G., and Duchemin, B.: Analysis of evaporative fraction diurnal behavior, Agr. Forest Meteorol., 143, 13-29, 2007. 
Guichard, F., Kergoat, L., Mougin, E., Timouk, F., Baup, F., Hiernaux, P., and Lavenu, F.: Surface thermodynamics and radiative budget in the Sahelian Gourma: Seasonal and diurnal cycles, J. Hydrol., 375, 161-177, https://doi.org/10.1016/j.jhydrol.2008.09.007, 2009.

Guo, Z., Dirmeyer, P. A., Koster, R. D., Sud, Y. C., Bonan, G., Oleson, K. W., Chan, E., Verseghy, D., Cox, P., Gordon, C. T., McGregor, J. L., Kanae, S., Kowalczyk, E., Lawrence, D., Liu, P., Mocko, D., Lu, C.-H., Mitchell, K., Malyshev, S., McAvaney, B., Oki, T., Yamada, T., Pitman, A., Taylor, C. M., Vasic, R., and Xue, Y.: GLACE: The Global Land Atmosphere Coupling Experiment. Part II: Analysis, J. Hydrometeorol., 7, 611-625, https://doi.org/10.1175/JHM511.1, 2006.

Guyot, A., Cohard, J.-M., Anquetin, S., Galle, S., and Lloyd, C. R.: Combined analysis of energy and water balances to estimate latent heat flux of a sudanian small catchment, J. Hydrol., 375, 227-240, https://doi.org/10.1016/j.jhydrol.2008.12.027, 2009.

Guyot, A., Cohard, J.-M., Anquetin, S., and Galle, S.: Long-term observations of turbulent fluxes over heterogeneous vegetation using scintillometry and additional observations: A contribution to AMMA under SudanoSahelian climate, Agr. Forest Meteorol., 154-155, 84-98, https://doi.org/10.1016/j.agrformet.2011.10.008, 2012.

Hall, F. G., Huemmrich, K. F., Goetz, S. J., Sellers, P. J., and Nickeson, J. E.: Satellite Remote Sensing of Surface Energy Balance Success, Failures, and Unresolved Issues in FIFE, J. Geophys. Res., 97, 19061-19089, 1992.

Higgins, C. W.: A-posteriori analysis of surface energy budget closure to determine missed energy pathways, Geophys. Res. Lett., 39, 1-5, https://doi.org/10.1029/2012GL052918, 2012.

Ingelrest, F., Barrenetxea, G., Schaefer, G., Vetterli, M., Couach, O., and Parlange, M.: SensorScope, ACM Trans. Sens. Netw., 6, 1-32, https://doi.org/10.1145/1689239.1689247, 2010.

Katul, G. G. and Parlange, M. B.: A Penman-Brutsaert Model for Wet Surface Evaporation, Water Resour. Res., 28, 121-126, 1992.

Krishnan, P., Meyers, T. P., Scott, R. L., Kennedy, L., and Heuer, M.: Energy exchange and evapotranspiration over two temperate semi-arid grasslands in North America, Agr. Forest Meteorol., 153, 31-44, https://doi.org/10.1016/j.agrformet.2011.09.017, 2012.

Kustas, W. P., Rango, A., and Uijlenhoet, R.: A simple energy budget algorithm for the snowmelt runoff model, Water Resour. Res., 30, 1515-1527, https://doi.org/10.1029/94WR00152, 1994.

Leuning, R.: The correct form of the Webb, Pearman and Leuning equation for eddy fluxes of trace gases in steady and non-steady state, horizontally homogeneous flows, Bound.-Lay. Meteorol., 123, 263-267, 2007.

Lhomme, J.-P. and Elguero, E.: Examination of evaporative fraction diurnal behaviour using a soil-vegetation model coupled with a mixed-layer model, Hydrol. Earth Syst. Sci., 3, 259-270, https://doi.org/10.5194/hess-3-259-1999, 1999.

Lohou, F., Saïd, F., Lothon, M., Durand, P., and Serça, D.: Impact of Boundary-Layer Processes on Near-Surface Turbulence Within the West African Monsoon, Bound.-Lay. Meteorol., 136, 1-23, https://doi.org/10.1007/s10546-010-9493-0, 2010.

Lohou, F., Kergoat, L., Guichard, F., Boone, A., Cappelaere, B., Cohard, J.-M., Demarty, J., Galle, S., Grippa, M., Peugeot, C., Ramier, D., Taylor, C. M., and Timouk, F.: Surface response to rain events throughout the West African monsoon, Atmos. Chem. Phys., 14, 3883-3898, https://doi.org/10.5194/acp-143883-2014, 2014.

Mamadou, O., Cohard, J. M., Galle, S., Awanou, C. N., Diedhiou, A., Kounouhewa, B., and Peugeot, C.: Energy fluxes and surface characteristics over a cultivated area in Benin: daily and seasonal dynamics, Hydrol. Earth Syst. Sci., 18, 893-914, https://doi.org/10.5194/hess-18-893-2014, 2014.

Mamadou, O., Galle, S., Cohard, J.-M., Peugeot, C., Kounouhewa, B., Biron, R., Hector, B., and Zannou, A. B.: Dynamics of water vapor and energy exchanges above two contrasting Sudanian climate ecosystems in Northern Benin (West Africa): WATER VAPOR AND ENERGY EXCHANGES, J. Geophys. Res.-Atmos., 121, 11269-11286, https://doi.org/10.1002/2016JD024749, 2016.

Mande, T.: Hydrology of the Sudanian Savannah in West Africa, Burkina Faso, PhD thesis, Swiss Federal Institute of Technology, Lausanne, Lausanne, Switzerland, 17 January, available at: https://infoscience.epfl.ch/record/195231/files/ EPFL_TH6011.pdf (last access: 4 October 2015), 2014.

Mande, T., Ceperley, N., Barrenetxea, G., Repetti, A., and Niang, D.: Rainfall-Runoff Processes in a Mixed Sudanian Savanna Agriculture Catchment?: Use of a distributed sensor network, in: Geophysical Research Abstracts, vol. 13, p. 1, Vienna, Austria, 2011.

Mauder, M., Jegede, O. O., Okogbue, E. C., Wimmer, F., and Foken, T.: Surface energy balance measurements at a tropical site in West Africa during the transition from dry to wet season, Theor. Appl. Climatol., 89, 171-183, https://doi.org/10.1007/s00704006-0252-6, 2006.

Nadeau, D. F., Brutsaert, W., Parlange, M. B., Bou-Zeid, E., Barrenetxea, G., Couach, O., Boldi, M.-O., Selker, J. S., and Vetterli, M.: Estimation of urban sensible heat flux using a dense wireless network of observations, Environ. Fluid Mech., 9, 635-653, https://doi.org/10.1007/s10652-009-9150-7, 2009.

Nicholson, S. E., Tucker, C. J., and Ba, M. B.: Desertification, drought, and surface vegetation: An example from the West African Sahel, B. Am. Meteorol. Soc., 79, 815-830, 1998.

Oldroyd, H. J., Pardyjak, E. R., Huwald, H., and Parlange, M. B.: Adapting Tilt Corrections and the Governing Flow Equations for Steep, Fully Three-Dimensional, Mountainous Terrain, Bound.Lay. Meteorol., 159, 539-565, 2015.

Parlange, M. B. and Katul, G. G.: Estimation of the diurnal variation of potential evaporation from a wet bare soil surface, J. Hydrol., 132, 71-89, https://doi.org/10.1016/0022-1694(92)90173S, 1992.

Pielke, R. A., Marland, G., Betts, R. A., Chase, T. N., Eastman, J. L., Niles, J. O., Niyogi, D. D. S., and Running, S. W.: The influence of land-use change and landscape dynamics on the climate system: relevance to climate-change policy beyond the radiative effect of greenhouse gases, Philos. T. R. Soc. A, 360, 1705-1719, 2002.

Porte-Agel, F., Parlange, M. B., Cahill, A. T., Gruber, A., and Porte, F.: Mixture of Time Scales in Evaporation?: Desorption and SelfSimilarity of Energy Fluxes, Agron. J., 92, 832-836, 2000.

Ramier, D., Boulain, N., Cappelaere, B., Timouk, F., Rabanit, M., Lloyd, C. R., Boubkraoui, S., Métayer, F., Descroix, L., and Wawrzyniak, V.: Towards an understanding of coupled physical and biological processes in the culti- 
vated Sahel - 1. Energy and water, J. Hydrol., 375, 204-216, https://doi.org/10.1016/j.jhydrol.2008.12.002, 2009.

Rebmann, C., Kolle, O., Heinesch, B., Queck, R., Ibrom, A., and Aubinet, M.: Data Acquisition and Flux Calculations, in: Eddy Covariance, edited by: Aubinet, M., Vesala, T., and Papale, D., Springer Netherlands, 59-83, https://doi.org/10.1007/97894-007-2351-1, 2012.

Santos, C. A. C. D., Silva, B. B. D., and Rao, T. V. R.: Analysis of the evaporative fraction using eddy covariance and remote sensing techniques, Rev. Bras. Meteorol., 25, 427-436, https://doi.org/10.1590/S0102-77862010000400002, 2010.

Schüttemeyer, D., Moene, A. F., Holtslag, A. A. M., Bruin, H. A. R., and Giesen, N. V.: Surface Fluxes and Characteristics of Drying Semi-Arid Terrain in West Africa, Bound.-Lay. Meteorol., 118, 583-612, https://doi.org/10.1007/s10546-005-9028-2, 2006.

Shuttleworth, W. J., Gurney, R. J., Hsu, A. Y., and Ormsby, J. P.: FIFE: the variation in energy partition at surface flux sites, Remote Sensing and Large-Scale Global Processes, Proceedings of the IAHS Third Int. Assembly, Baltimore, MD, USA, May 1989, IAHS Publ. no. 186, 1989.

Simoni, S., Padoan, S., Nadeau, D. F., Diebold, M., Porporato, A., Barrenetxea, G., Ingelrest, F., Vetterli, M., and Parlange, M. B.: Hydrologic response of an alpine watershed: Application of a meteorological wireless sensor network to understand streamflow generation, Water Resour. Res., 47, W10524, https://doi.org/10.1029/2011WR010730, 2011.

Steiner, A. L., Pal, J. S., Rauscher, S. A., Bell, J. L., Diffenbaugh, N. S., Boone, A., Sloan, L. C., and Giorgi, F.: Land surface coupling in regional climate simulations of the West African monsoon, Clim. Dynam., 33, 869-892, 2009.

Swanson, R. A.: Gourmantche agriculture, Ouagadougou USAID, Development Anthropology Technical Assistance Component, Integrated Rural Development Project, Eastern ORD, BAEP, Upper Volta Contract AID-686-049-78, USAID, Washington, D.C., USA, 1978.

Swets, D. L., Reed, B. C., Rowland, J. D., and Marko, S. E.: A weighted least-squares approach to temporal NDVI smoothing, in: Proceedings of the 1999 ASPRS Annual Conference, 17-21 May 1999, Portland, Oregon, USA, available at: https: //phenology.cr.usgs.gov/pubs/ASPRSSwetsetalSmoothing.pdf (last access: 16 August 2017), 1999.

Sylla, M. B., Pal, J. S., and Wang, G.: Impact of land cover characterization on regional climate modeling over West Africa, Clim. Dynam., 46, 637-650, 2015.

Szilagyi, J. and Parlange, M. B.: Defining Watershed-Scale Evaporation Using a Normalized Difference Vegetation Index, J. Am. Water Resour. As., 35, 1245-1255, https://doi.org/10.1111/j.1752-1688.1999.tb04211.x, 1999.
Szilagyi, J., Rundquist, D. C., Gosselin, D. C., and Parlange, M. B.: NDVI relationship to monthly evaporation, Geophys. Res. Lett., 25, 1753-1756, 1998.

Timouk, F., Kergoat, L., Mougin, E., Lloyd, C. R., Ceschia, E., Cohard, J.-M., Rosnay, P., Hiernaux, P., Demarez, V., and Taylor, C. M.: Response of surface energy balance to water regime and vegetation development in a Sahelian landscape, J. Hydrol., 375, 178-189, 2009.

Topp, G. C., Davis, J. L., and Annan, A. P.: Electromagnetic determination of soil water content: Measurements in coaxial transmission lines, Water Resour. Res., 16, 574-582, https://doi.org/10.1029/WR016i003p00574, 1980.

Velluet, C., Demarty, J., Cappelaere, B., Braud, I., Issoufou, H. B.-A., Boulain, N., Ramier, D., Mainassara, I., Charvet, G., Boucher, M., Chazarin, J.-P., Oï, M., Yahou, H., Maidaji, B., Arpin-Pont, F., Benarrosh, N., Mahamane, A., Nazoumou, Y., Favreau, G., and Seghieri, J.: Building a field- and model-based climatology of local water and energy cycles in the cultivated Sahel - annual budgets and seasonality, Hydrol. Earth Syst. Sci., 18, 5001-5024, https://doi.org/10.5194/hess-18-5001-2014, 2014.

Vitousek, P. M.: Human Domination of Earth's Ecosystems, Science, 277, 494-499, https://doi.org/10.1126/science.277.5325.494, 1997.

Webb, E., Pearman, G., and Leuning, R.: Correction of flux measurements for density effects due to heat and water vapour transfer, Q. J. Roy. Meteorol. Soc., 106, 85-100, 1980.

White, F.: La vegetation de l'Afrique: Memoire accompagnant la carte de vegetation de l'Afrique, vol. 20, IRD Editions, Paris, France, 1986.

Whiteman, C. D. and Allwine, K. J.: Extraterrestrial solar radiation on inclined surfaces, Environ. Softw., 1, 164-169, 1986.

Wilczak, J. M., Oncley, S. P., and Stage, S. A.: Sonic anemometer tilt correction algorithms, Bound.-Lay. Meteorol., 99, 127-150, 2001.

Williams, C. A., Reichstein, M., Buchmann, N., Baldocchi, D., Beer, C., Schwalm, C., Wohlfahrt, G., Hasler, N., Bernhofer, C., Foken, T., Papale, D., Schymanski, S., and Schaefer, K.: Climate and vegetation controls on the surface water balance: Synthesis of evapotranspiration measured across a global network of flux towers, Water Resour. Res., 48, W06523, https://doi.org/10.1029/2011WR011586, 2012. 